\title{
Dietary Inflammatory Index and Non-Communicable Disease Risk: A Narrative Review
}

\author{
Catherine M. Phillips ${ }^{1,2, *}{ }^{\mathbb{C}}$, Ling-Wei Chen ${ }^{1}\left(\mathbb{D}\right.$, Barbara Heude ${ }^{3} \mathbb{D}^{-}$, Jonathan Y. Bernard ${ }^{3}(\mathbb{D}$, \\ Nicholas C. Harvey ${ }^{4}$, Liesbeth Duijts ${ }^{5,6,7}$, Sara M. Mensink-Bout ${ }^{5,6}$, Kinga Polanska ${ }^{8} \mathbb{D}_{\text {, }}$ \\ Giulia Mancano ${ }^{9}$, Matthew Suderman ${ }^{9}$, Nitin Shivappa ${ }^{10}$ and James R. Hébert ${ }^{10,11}$ \\ 1 HRB Centre for Diet and Health Research, School of Public Health, Physiotherapy, and Sports Science, \\ University College Dublin, Belfield, Dublin 4, Ireland \\ 2 HRB Centre for Diet and Health Research, School of Public Health, University College Cork, \\ Western Gateway Building, Western Rd, Cork, Co. Cork, Ireland \\ 3 Research Team on the Early Life Origins of Health (EAROH), Centre for Research in Epidemiology and \\ Statistics (CRESS), INSERM, Université de Paris, F-94807 Villejuif, France \\ 4 MRC Lifecourse Epidemiology Unit, University of Southampton, Southampton General Hospital, \\ Southampton SO16 6YD, UK \\ 5 The Generation R Study Group, Erasmus MC, University Medical Center, P.O. Box 2040, \\ 3000 CA Rotterdam, The Netherlands \\ 6 Department of Pediatrics, Division of Respiratory Medicine and Allergology, Erasmus MC, University \\ Medical Center, P.O. Box 2060, 3000 CB Rotterdam, The Netherlands \\ 7 Department of Pediatrics, Division of Neonatology, Erasmus MC, University Medical Center, P.O. Box 2060, \\ 3000 CB Rotterdam, The Netherlands \\ 8 Department of Environmental Epidemiology, Nofer Institute of Occupational Medicine, 91-348 Lodz, Poland \\ 9 MRC Integrative Epidemiology Unit, Population Health Sciences, Bristol Medical School, \\ University of Bristol, Bristol BS8 2BN, UK \\ 10 Cancer Prevention and Control Program and Department of Epidemiology and Biostatistics, \\ Arnold School of Public Health, University of South Carolina, Columbia, SC 29208, USA \\ 11 Connecting Health Innovations LLC, Columbia, SC 29201, USA \\ * Correspondence: catherine.phillips@ucd.ie
}

Received: 18 June 2019; Accepted: 5 August 2019; Published: 12 August 2019

\begin{abstract}
There are over 1,000,000 publications on diet and health and over 480,000 references on inflammation in the National Library of Medicine database. In addition, there have now been over 30,000 peer-reviewed articles published on the relationship between diet, inflammation, and health outcomes. Based on this voluminous literature, it is now recognized that low-grade, chronic systemic inflammation is associated with most non-communicable diseases (NCDs), including diabetes, obesity, cardiovascular disease, cancers, respiratory and musculoskeletal disorders, as well as impaired neurodevelopment and adverse mental health outcomes. Dietary components modulate inflammatory status. In recent years, the Dietary Inflammatory Index (DII $\left.{ }^{\circledR}\right)$, a literature-derived dietary index, was developed to characterize the inflammatory potential of habitual diet. Subsequently, a large and rapidly growing body of research investigating associations between dietary inflammatory potential, determined by the DII, and risk of a wide range of NCDs has emerged. In this narrative review, we examine the current state of the science regarding relationships between the DII and cancer, cardiometabolic, respiratory and musculoskeletal diseases, neurodevelopment, and adverse mental health outcomes. We synthesize the findings from recent studies, discuss potential underlying mechanisms, and look to the future regarding novel applications of the adult and children's DII (C-DII) scores and new avenues of investigation in this field of nutritional research.
\end{abstract}

Keywords: dietary inflammatory index; inflammation; cardiometabolic health; obesity; metabolic syndrome; cancer; respiratory health; bone health; mental health; neurodevelopment 


\section{Introduction}

Non-communicable diseases (NCDs) are a major contributor to the global burden of disease and account for up to $72 \%$ of worldwide deaths [1]. Chronic low-grade inflammation, characterized by persistent elevated concentrations of circulating pro-inflammatory cytokines, across the life span has been associated with the development of both age and diet-related NCDs, including obesity, cardiometabolic diseases, many cancers, respiratory and auto-immune disorders, arthritis, and depression [2-4]. The link between dietary habits and NCDs has been extensively examined $[5,6]$. Many NCDs are, to a large extent, preventable and modifiable lifestyle-related risk factors including an unhealthy diet play a significant role [7-12]. The Global Burden of Diseases Nutrition and Chronic Diseases Expert Group examined global dietary quality trends among adults across 187 nations over 20 years (1990-2010). They reported a modest increase in the consumption of healthy foods over that time; however, this was surpassed by a greater increase in intake of unhealthy foods [13]. Furthermore this study highlighted the potential impact of suboptimal diet on NCD risk and mortality and the need to improve diet on a worldwide scale.

It is now recognized that diet is an important modulator of chronic inflammation [14]. Current evidence on the influence of diet on inflammation is based on different research approaches; i.e., nutrient-based, food group-based or analyses of whole-diet patterns. Examination of dietary patterns and indices has become more popular given the ease with which these measures can be generated from existing dietary data. Additionally, considering that we eat complex combinations of foods, rather than individual nutrients and food groups, such approaches are also more translatable in terms of public health messaging. However some common and method-specific limitations exist [15]. The dietary inflammatory index (DII $\left.{ }^{\circledR}\right)$ was developed to characterize the inflammatory potential of the diet. In contrast to dietary indices used in epidemiologic research which have traditionally been based on adherence to dietary guidelines or recommendations including the Dietary Approaches to Stop Hypertension [16], the Healthy Eating Index-2010, the Alternative Healthy Eating Index [17-19]; adherence to specific foods or gastronomy such as the Mediterranean Dietary Index [20-22]; or study-specific derivations from regression techniques such as principal components analysis or reduced rank regression [23-25], the DII design is based on a wider range of human populations, study designs, and nutritional assessment methods [26]. Furthermore, the DII also includes evidence from qualifying cell culture and animal experiments [27].

Since its development the DII has been widely studied in various disease contexts to test the hypothesis that dietary inflammation is a determinant of NCD risk and mortality. Consistent with previous reports, recent data from 2 large Spanish prospective studies ( $\mathrm{n}=18,566$ participants in total) provide strong evidence that inflammatory mechanisms link unhealthy diet and premature death [7]. The authors additionally included their findings in a meta-analysis with 10 studies included in previous meta-analyses investigating DII and mortality. They reported a $23 \%$ increased risk of all-cause mortality comparing highest vs. lowest DII categories [7], confirming that a pro-inflammatory diet is linked to greater all-cause mortality risk. In this narrative review, we examine the recent literature regarding relationships between the DII and NCD risk. We distill key findings, discuss potential underlying mechanisms, and conclude with future directions and new avenues of investigation for this area of nutritional research.

\section{DII Development}

Work to develop the DII began in 2004 and the paper describing the DII Generation (Gen) 1 method and construct validation was published in 2009 [26]. In 2014, we produced a refinement (Gen2) that included an improved scoring system, more complete literature search, and a comparative food and nutrient database that included data from 11 countries on four continents [27]. The entire process of developing the DII is described in our methods paper [27] and the steps involved are shown in Figure 1. The first step was to review all of the articles published through 2010 that studied at least one of the six inflammatory markers (i.e., c-reactive protein (CRP), interleukin (IL)- $1 \beta$, IL-4, IL-6, 
IL-10, and tumor necrosis factor- $\alpha(\mathrm{TNF}-\alpha)$. Each food parameter was given a literature-derived inflammatory effect score based on scoring of articles, which depends on (1) study design, (2) direction of the association between the food parameter and inflammatory markers, and (3) strength and dose-response of the association. The final three steps involve relating an individual score to the global database comparison. This requires: (1) Z-scoring each parameter and then converting these Z-scores to a proportion and centering by doubling and subtracting 1 ; (2) multiplying each of these centered proportions by the respective overall food parameter-specific inflammatory effect score to obtain the food parameter-specific DII score; and (3) summing all of these food parameter-specific DII scores to create the overall DII score for each study participant.

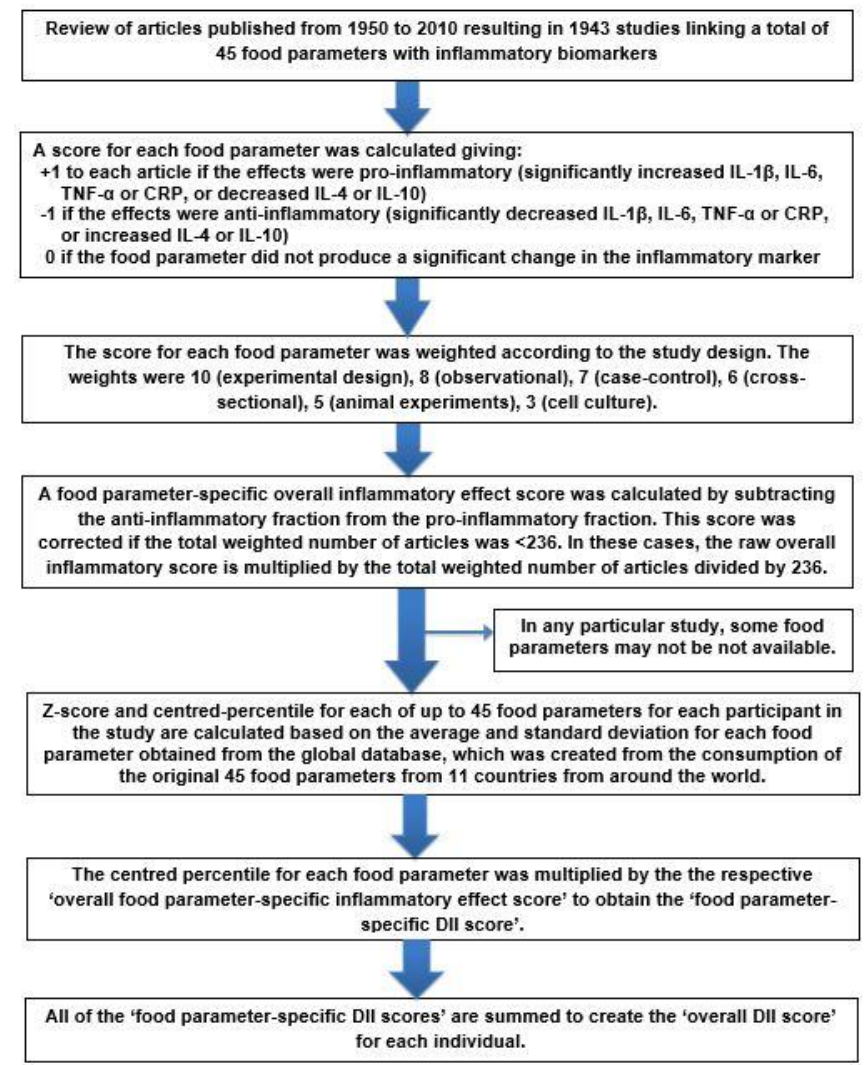

Figure 1. Sequence of steps in creating the Dietary Inflammatory Index (DII $\left.{ }^{\circledR}\right)$.

Using methods of construct validation, we showed that the DII could predict interval changes in levels of high-sensitivity CRP (hs-CRP) in the Seasonal Variation in Blood Lipids (SEASONS) study in which dietary data were collected using both multiple (i.e., up to 15) $24 \mathrm{~h}$ recall interviews (24 h), five administrations of a structured questionnaire, the seven-day dietary recall [28], and up to five hs-CRP measures [29]. We have now tested the effect of diet-associated inflammation on inflammation markers, including CRP, IL-6, IL-4, and TNF- $\alpha$ receptor-2 [30-36]. Some of these studies were conducted with the sole purpose of validation $[29,32,37]$. In some studies examining DII and health outcome associations, validation was carried out as part of the larger study [38-40]. We also have tested effects on other markers of disease risk such as homocysteine, chemerin, fibrinogen, complement component C3, leukocytes/white blood cells, interferons, intercellular adhesion molecule, and vascular cell adhesion molecule 1 [31,33,41]. The DII or energy-adjusted DII (E-DII) have been construct validated against inflammatory biomarkers in different populations and under varying conditions [12,29,31,33-48]. More recently the children's DII (C-DII) has been developed and construct validated with hs-CRP in an American study [49]. 


\section{Methods}

This is a narrative review of the current literature on the DII and NCD risk. The literature search performed in PubMed and Scopus included the following keywords, used separately and in combination: Dietary inflammatory index, NCD; cancer; type 2 diabetes, gestational diabetes, cardiovascular disease; cardiometabolic disease, obesity, metabolic syndrome, bone, musculoskeletal, neurodevelopment, mental health, depression, anxiety, respiratory health, and asthma. The inclusion criteria were peer-reviewed human studies, meta-analyses and systematic reviews from 2014 to May 31st 2019, so that the focus is on associations with the refined (i.e., generation 2) DII. Please note that all measures of association; e.g., odds ratios (ORs), hazard ratios (HRs), are adjusted for potential confounders, though these may vary in type and number across studies.

\section{DII and Cancers}

Since Virchow first proposed the connection between inflammation and cancer in the mid-19th century [50], interest in the relationship between factors that influence inflammation and cancer has continued to grow [51-54]. We now know that inflammation is not a single cancer-related mechanism. Rather, it is a substrate on which other mechanisms operate, including oxidative and nitrative DNA damage, changes in gene expression and genetic instability, insulin resistance, blunted immune response, neural signaling, and vascular dysfunction [55-67]. The DII concept arose in the context of conducting cancer research to address the conceptual and methodologic gaps between the burgeoning fields of inflammation-related and dietary research. Until the DII was developed there was no evidence-based tool to link diet-related inflammation to cancer or other health outcomes [15]. It is, therefore, no surprise that a major focus of DII research has been on its link with cancer. We have now published over 100 papers on the DII in relation to cancers of various anatomic/organ sites. In addition, other groups have published numerous papers based on the DII in relation to cancer, including several meta-analyses [51-54,68-70]. The vast majority of these publications have shown a positive association between increasing inflammatory potential of diet and cancer risk and mortality after a cancer diagnosis.

\subsection{Colorectal Cancer (CRC)}

Because of its strong association with inflammatory bowel disease (IBD), CRC has been known to be related to inflammation [71]. Furthermore, biomarkers of inflammation are known to be associated with CRC risk [72,73] and CRC's connection with diet has been established for some time [74-77]. Therefore, it is not surprising that we have observed consistently strong positive relationships between the DII score and CRC. At this juncture, there are 13 papers published by our group on CRC incidence [42,78-89] from studies carried out in various populations across the world [81,82].

We have also published one meta-analysis [10], which showed that individuals in the highest versus the lowest (reference) DII category had an overall $40 \%$ increase in CRC risk of [relative risk $(\mathrm{RR})=1.40,95 \%$ confidence interval $(\mathrm{CI}): 1.26,1.55, p<0.001]$. Increase of this magnitude in a cancer that has the potential to kill has great public health significance. In the most recent publication from Spain [82], E-DII was associated with CRC risk in the highest, most pro-inflammatory E-DII quartile vs the lowest quartile $\left(\mathrm{OR}_{\mathrm{E}-\mathrm{DIIQuartile4vs1}}=1.93,95 \%\right.$ CI: 1.60-2.32; $\left.\mathrm{P}_{\text {trend }}<0.001\right)$; this increase was observed for both colon and rectal cancer [82]. Because all risk estimates are based on exposures seen in actual populations, the measures of association actually underestimate potential risk because the variability we see within populations (usually around -5 to +5 ) is much less than the maximal theoretical range (around -9 to +8 ). When analyzed as a continuous variable, results showed a $7 \%$ increase in CRC risk for each 1-point increase in the DII score; this translates to more than doubling $(119 \%)$ in risk for the most pro-inflammatory diet relative to the most anti-inflammatory.

We have published three [90-92] papers on mortality in colorectal cancer survivors in relation to the DII or the E-DII. Results reflect a strong and consistently positive relationship between DII 
score and overall mortality (e.g., in the Women's Health Initiative showed that women in the lowest tertile of E-DII scores from diet plus supplements has less than half the rate of all-cause mortality compared to those women in the highest, most pro-inflammatory, E-DII tertile $\left(\mathrm{HR}_{\text {Tertile1vs3 }}=0.49\right.$; 95\% CI $=0.31-0.79$ ) [92].

We also have published three papers on adenomatous polyps (CRC precursor lesions) and the DII. Results from these studies are not as consistently positive as those for CRC incidence, survival, or mortality. One of these, based on data from the Prostate, Lung, Colorectal, and Ovarian (PLCO) Cancer Screening Trial, showed a positive effect in both men and women, but with stronger associations in men (e.g., about a 40\% increase in risk in quartile 4 (most pro-inflammatory diet) versus quartile 1 $\left(\mathrm{OR}_{\mathrm{Quartile4vs1}}=1.41 ; 95 \% \mathrm{CI}=1.23-1.62\right)$ [93]. Findings from another study in the US, focusing on recurrent colorectal adenomas, produced null effects [94]. The most recent study, from Iran, shows a consistent positive association, with greater than twice the odds of adenomas in the $3^{\text {rd }}$ vs $1^{\text {st }}$ tertile $\left(\mathrm{OR}_{\text {Tertile3vs1 }}=2.33 ; 95 \% \mathrm{CI}: 1.30-4.02 ; \mathrm{P}_{\text {trend }}=0.005\right)$ [82]. Given the role of the microbiome in the colon and IBD [95] and the role of diet in modulating the microbiota [96,97], this is a frontier area that should be pursued. Recent evidence showing that the DII affects urinary enterolignans, compounds produced as a result of action by the microbiota, is very encouraging in this regard [39].

\subsection{Cancers of the Upper Aerodigestive Tract}

As a group, cancers of the upper aerodigestive tract, which include cancers of the larynx, nasopharynx, oral and pharynx, and esophagus, are strongly associated with tobacco, which, among its other properties, is known to be intensely pro-inflammatory [98,99]. Indeed, after CRC the most consistent, positive associations with DII scores have been for cancers of the upper aerodigestive tract. In general, these associations with DII are stronger than those observed for CRC. For example, three studies on laryngeal cancer [78,100,101] produced positive results, with more than a tripling of risk across DII quartiles in an Italian case-control study [100] (OR Quartile4vs1 $=3.30 ; 95 \%$ CI 2.06, 5.28; $\left.P_{\text {trend }}<0.0001\right)$, and an even stronger effect in smokers $\left(O R_{Q u a r t i l e 4 v s 1}=4.86\right)$ and overweight subjects $\left(\mathrm{OR}_{\text {Quartile4vs1 }}=3.62\right)$.

Studies on nasopharyngeal cancer $[78,102,103]$ also produced positive results, with those in the highest tertile compared to subjects in the lowest DII tertile, having a $>60 \%$ higher risk in Italy (OR Tertile4vs1 = 1.64; 95\% CI: 1.06-2.55) [104]; while those in the highest DII quartile in Japan had a $>4$-fold higher risk relative to subjects with the most anti-inflammatory diets (OR Quartile4vs1 $_{1}=4.99 ; 95 \%$ CI: 1.14-21.79) [103]. Likewise, our one study on oral and pharyngeal cancer in Italy [104] showed that subjects with DII scores in the highest quartile were at nearly double the risk, of oral and pharyngeal cancer $\left(\mathrm{OR}_{\mathrm{Quartile4vs1}}=1.80 ; 95 \%\right.$ CI 1.36-2.38). We also observed a strong combined effect of higher DII score and tobacco smoking or alcohol consumption on oral and pharyngeal cancer, which is consistent with the synergistic effect of alcohol, tobacco and a pro-inflammatory diet.

Esophagus is the site where one would expect to see the strongest effect if there were actual mixing between dietary constituents and tobacco smoke condensates [105,106]. Indeed, we have seen the strongest associations between the DII and esophageal cancer [78,103,107-111]. For example, looking at esophageal squamous cell cancer in Iran, we observed a very strong linear effect of the DII $\left(\mathrm{OR}_{\text {continuous }}=3.58,95 \% \mathrm{CI}\right.$ : 1.76-7.26) [107]; in Italy a strong effect across quintiles $\left(\mathrm{OR}_{\text {quintile5vs } 1} 2.46\right.$, $95 \%$ CI 1.40-4.36; $\mathrm{P}_{\text {trend }}<0.001$ ) [108]; and an even stronger effect in Sweden (OR Quartile4vs1 $_{4.35,95 \%}$ CI 2.24, 8.43) [109]. We also have observed strong associations with adenocarcinoma of the esophagus in Ireland $\left(\mathrm{OR}_{\text {Tertile3vs1 }}=2.29 ; 95 \% \mathrm{CI}: 1.32-3.96\right)$ [110] and Sweden $\left(\mathrm{OR}_{\mathrm{Quartile} 4 \mathrm{vs} 1}=3.59,95 \%\right.$ CI: 1.87-6.89) [109] and in overall esophageal cancer in China (OR ${ }_{Q u a r t i l e 4 v s 1}=2.55 ; 95 \%$ CI: 1.61-4.06; $\left.\mathrm{P}_{\text {trend }}<0.001\right)[111]$.

\subsection{Other Tobacco-Related Cancers}

Given the ability of diet and tobacco to modulate inflammation, it would not be surprising to find strong associations between the DII and risk of other tobacco-related sites. Indeed, we have 
now observed associations between the DII/E-DII and lung cancer in the Melbourne Collaborative Cohort Study $(\mathrm{n}=35,303)$ in Australia where the hazards ratio comparing quartile 4 to quartile 1 was $\left(1.7095 \%\right.$ CI 1.02, 2.82, $\mathrm{P}_{\text {trend }}=0.008$ ] [112] and in current smokers $\left(\mathrm{HR}_{\mathrm{Q} 5 \mathrm{vsQ} 1}=1.44 ; 95 \% \mathrm{CI}\right.$ $\left.1.11-1.86, \mathrm{P}_{\text {trend }}=0.03\right)$ and in male ever-smokers $\left(\mathrm{HR}_{\mathrm{Quintile5vs}}=1.37 ; 95 \% \mathrm{CI} 1.07-1.77 ; \mathrm{P}_{\text {trend }}=\right.$ 0.03) in Singapore [113]. However, in Sweden, the association was only marginally significant (with the reduction in $\mathrm{HR}_{\text {per-tertile decrease }}=0.81$; 95\% CI 0.66-0.99) [114] and in Italy no relationship with the DII was observed, though there was radiological evidence of emphysema across DII quartiles $\left(\mathrm{OR}_{\text {Quartile4vs1 }}=1.30,95 \%\right.$ CI 1.01-1.67, $\left.\mathrm{P}_{\text {trend }}=0.01\right)$ [115].

We have also observed associations between the DII and urinary bladder cancer in analyses of data from elderly subjects in a pooled case-control in Italy $\left(\mathrm{OR}_{\text {continuous }}=1.08,95 \%\right.$ CI: 1.00-1.17); $\left.P_{\text {trend }}=0.003\right)[78]$ and in separate case-control studies in Italy $\left(\mathrm{OR}_{\text {Quartile4vs1 }}=1.97,95 \%\right.$ CI: 1.28-3.03; $\left.P_{\text {trend }}=0.003\right)[116]$ and Iran $\left(\mathrm{OR}_{\text {above vs below median }}=2.46 ; 95 \% \mathrm{CI}=1.12-5.41\right)$ [117]. Two studies on renal cancer, both showing positive results, have been conducted in a prospective study of women in Iowa in the USA $\left(\mathrm{HR}_{\text {DIItertile3vs1 }}=1.52 ; 95 \% \mathrm{CI}: 1.09,2.13\right)$ [118] and in an Italian case-control study $\left(\mathrm{OR}_{\text {Quartile4vs1 }}=1.41,95 \%\right.$ CI: $\left.1.02-1.97 ; \mathrm{P}_{\text {trend }}=0.04\right)[119]$.

\subsection{Other Digestive Tract Sites}

We have also observed generally strong relationships between the DII and pancreatic cancer risk [78,120-122]. These associations are similar in scale to what we have observed for cancers of the aerodigestive tract. For example, extreme quintile comparisons from the patient registry supported by the Mayo Clinic Specialized Program of Research Excellence (SPORE) in Pancreatic Cancer at the Mayo Clinic showed extreme DII quintile comparisons of about 2.5-fold increased risk $\left(\mathrm{OR}_{\text {Quintile5vs1 }}=2.54,95 \% \mathrm{CI}: 1.87-3.46, \mathrm{P}_{\text {trend }}<0.0001\right)$ and even more extreme results among current smokers (OR $\mathrm{Ouintile5vs}_{1}=3.40,95 \% \mathrm{CI}$ : 2.28-5.07) and among participants with long-standing diabetes $\left(\mathrm{OR}_{\mathrm{Quintile5vs1}}=3.09,95 \% \mathrm{CI}\right.$ : 2.02-4.72), highlighting the importance of underlying inflammatory conditions for cancer risk [121]. However, it should be noted that we also have observed null results in the PLCO Trial [123] and the NIH-AARP Diet and Health Study [124]. Other digestive tract sites for which we have results, albeit from relatively fewer studies, include the liver. One study from Italy showing results of about the same magnitude as other cancers in this group for hepatocellular cancer $\left(\mathrm{OR}_{\mathrm{E}-\mathrm{DII}}\right.$ tertile 3vs1 $\left.=2.43,95 \% \mathrm{CI}: 1.27-4.68 ; \mathrm{P}_{\text {trend }}=0.03\right)$, with a stronger effect in hepatitis Band C-negative participants $\left(\mathrm{OR}_{\mathrm{E}-\mathrm{DII}}\right.$ tertile $\left.3 \mathrm{vs} 1=4.18,95 \% \mathrm{CI}: 1.53-11.39 ; \mathrm{P}_{\text {trend }}=0.02\right)$ [125]. Similarly,

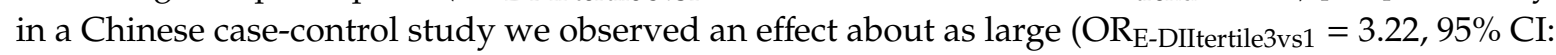
$\left.1.30-7.98, P_{\text {trend }}=0.009\right)$ [126]. One study each from Italy $\left(\mathrm{OR}_{\text {Quartile4vs1 }}=2.35,95 \%\right.$ CI: 1.32-4.20; $\left.P_{\text {trend }}=0.004\right)[127]$ and Iran $\left(\mathrm{OR}_{\mathrm{above}}\right.$ vs below median $\left.=3.39 ; 95 \% \mathrm{CI}=1.59-7.22,\right)[38]$ showed positive associations between DII scores and gastric cancer.

\subsection{Hormone-Sensitive Cancers}

Of the hormone-sensitive cancers, prostate cancer has been among the most consistently positively associated with the DII, with 11 studies showing a positive relationship [78,128-137]. In a meta-analysis of the DII in relation to prostate cancer, the adjusted pooled RR of prostate cancer for the highest (the most pro-inflammatory diet) versus lowest (the most anti-inflammatory diet) DII categories was 1.74 (95\% CI: 1.24-2.43) [68]. The analysis of the DII score as a continuous variable showed that the risk of prostate cancer was $9 \%$ higher for each one-point increase in the DII score [68]. We also have published one study on DII and survival from prostate cancer, which indicated that men with more poorly differentiated disease (Gleason score 7-10) were more like to die of all causes (HR ${ }_{\text {DIItertile3vs1 }}$ $=2.88 ; 95 \%$ CI: $1.46-5.67) 2.88 ; 95 \%$ CI: $1.46-5.67)$ and prostate cancer $\left(\right.$ HR $_{\text {DIItertile3vs } 1}=2.82 ; 95 \%$ CI: 1.17-6.80) [138]. Results from breast cancer incidence-focused studies tend to be consistent with a positive association between the DII and incident disease [139-143], but on the whole results have been modest compared to other cancers. For example, in the prospective Swedish Women's Lifestyle Study there was about a $20 \%$ increase in being diagnosed with breast cancer across extreme DII quartiles 
$\left(\mathrm{HR}_{\text {DIIquartile4vs1 }}=1.18 ; 95 \% \mathrm{CI}: 1.00-1.39\right)$, with somewhat stronger associations in postmenopausal women ( $\mathrm{HR}_{\text {DIIquartile4vs1 }}=1.22 ; 95 \% \mathrm{CI}$ : 1.01-1.46) [139]. In addition, we have observed null results in some studies $[81,144,145]$. Results from studies in the US and Italy focusing on breast cancer survival have been consistently positive [146-148]. Furthermore in the Women's Health Initiative, E-DII scores were associated with a lower risk of CVD mortality $\left(\mathrm{HR}_{\mathrm{Quartile1vsQ4}}=0.44 ; 95 \% \mathrm{CI}=0.24-0.82 ; \mathrm{P}_{\text {trend }}\right.$ $=0.005)$, but not with breast cancer-specific mortality $\left(\mathrm{HR}_{\text {Quartile1vsQ4 }}=0.96 ; 95 \% \mathrm{CI}=0.62-1.49\right.$; $\left.\mathrm{P}_{\text {trend }}=0.96\right)$ or all-cause mortality $\left(\mathrm{HR}_{\mathrm{Quartile1vsQ4}}=0.82 ; 95 \% \mathrm{CI}=0.63-1.05 ; \mathrm{P}_{\text {trend }}=0.17\right)$ [146]. We have observed consistent positive results between the DII and ovarian cancer [149-151], including in African-American women, in whom we observed a 10\% increase in epithelial ovarian cancer risk per one-unit change in the E-DII (OR $=1.10,95 \% \mathrm{CI}=1.03-1.17)$ and in comparing women consuming the most pro-inflammatory diet compared to the most anti-inflammatory diet $\left(\mathrm{OR}_{\mathrm{E}-\mathrm{DIIQuartile4vs} 1}=1.72\right.$; $95 \% \mathrm{CI}=1.18-2.51$ ) [152]. In an Italian case-control study, women with the most pro-inflammatory diet had a higher risk for endometrial cancer compared with women with the most anti-inflammatory $\operatorname{diet}\left(\mathrm{OR}_{\mathrm{Quartile4vs} 1}=1.46,95 \% \mathrm{CI}: 1.02-2.11, \mathrm{P}_{\text {trend }}=0.04\right)[153]$.

\subsection{Lymphomas}

In two studies from Italy show higher that DII scores have been shown to be associated with an increased risk of Non-Hodgkin's Lymphoma (OR DIIQuartile4vs1 $=1.61,95 \%$ CI: 1.07-2.43; $\left.P_{\text {trend }}=0.01\right)$ [154], but not with Hodgkin's Lymphoma [155].

In summary, we have found consistent relationships between DII scores and cancer outcomes for a wide array of cancers. This is true across very diverse populations from around the world and using different dietary assessment methods-mostly different versions of food frequency questionnaires (FFQs). The most consistent results are for CRC, aerodigestive tract cancers, and prostate cancer. Studies that have produced null results tend to have shorter follow-up periods than most cohorts (e.g., the PLCO trial [123] and the NIH-AARP Diet and Health Study [124]) or case-control studies, which attempt to draw inferences between current diet and diet in the distant past.

\section{DII and Cardiometabolic Health and Disease}

Cardiometabolic disease encompasses a spectrum of conditions from insulin resistance progressing to clinically recognisable states of pre-diabetes, metabolic syndrome (MetS), and finally to cardiovascular disease (CVD) and type 2 diabetes mellitus (T2DM) [156]. These conditions are grouped under the same umbrella term as they share many risk factors such as dyslipidaemia, hypertension, and obesity [157]. Obesity is associated with low-grade inflammation within adipose tissue and the secretion of cytokine, leading to impaired lipid metabolism. It is worth noting that a substantial proportion of obese adults exhibit what has been described as a metabolically healthy obese phenotype, characterized by the absence of low-grade inflammation and other metabolic perturbations [158]. Other populations, including in East Asia (Korea) [159], South Asia (India) [160], West Asia (Iran) [161], and in African Americans [162], tend to be metabolically obese (i.e., they evince symptoms associated with obesity at lower levels of adiposity). CVD and T2DM are both leading causes of death [163] and pose substantial healthcare burdens worldwide. Chronic systemic inflammation, characterized by continuous elevated circulating levels of inflammatory cytokines, is implicated in the pathophysiology of CVD and T2DM [164-168]. As diet is a major determinant of inflammation, there is great interest in whether dietary inflammatory potential can modify an individual's risk of cardiometabolic diseases.

Recently, several (systematic) reviews and meta-analyses have been conducted to appraise evidence to date for the associations between DII and cardiometabolic disease [11,169-171]. Of these, three reviews focused on CVD, MetS, and mortality $[11,170,171]$, while the other focused on obesity and body mass index (BMI) [169]. In general, a more pro-inflammatory diet, as indicated by a higher DII score, has been associated with higher risk of obesity [169], CVD risk, and CVD-related mortality $[11,170,171]$, while the relationship between DII and MetS is less consistent $[170,171]$. 


\subsection{DII and CVD Risk and CVD Mortality}

Recent reviews unanimously concluded a consistent, direct association between a pro-inflammatory diet and higher CVD risk and mortality. In subgroup analyses of a meta-analysis, a high DII score was associated with higher risk of myocardial infarction, but not other types of CVD such as stroke and ischemic heart diseases [11]. Furthermore, sex (stronger in women than in men) and region (stronger in Europe, North America, and Japan than Australia) seemed to modify the relationship between DII and CVD. However, it should be noted that the number of studies for these subgroup analyses are low, and thus the results should be interpreted with caution. Studies published after these reviews also reported significant direct association between DII score and CVD risk (estimated from Framingham Risk Score) [172] and CVD mortality [9,173]. Nonetheless, subgroup analysis in our meta-analysis [11] also suggested that the association between DII and CVD risk or mortality is likely independent from the influence of BMI and lifestyle factors such as smoking and physical activity, as the pooled estimates remained statistically significant in studies that adjusted for these factors.

The SUN cohort in Spain is the largest study to date that has examined the relationship between DII and CVD incidence. It was reported that CVD risk was about twice as high (adjusted hazard ratio (HR): 2.03 ; 95\% CI: 1.06, 3.88; total $\mathrm{n}=18,794$ ) among participants in the highest quartile of DII score, as compared to the lowest quartile [174]. On the other hand, the largest study to date investigating DII vs. CVD related mortality was conducted in a multi-ethnic cohort in the USA (total $n=150,405$ ), which reported an adjusted HR of 1.13 (95\% CI: 1.03, 1.23) for men and 1.29 (95\% CI: 1.17-1.42) for women, comparing the highest vs. lowest tertiles of DII score [175]. Several potential mechanisms have been proposed to explain the putative influence of pro-inflammatory diet on CVD risk and mortality. For instance, pro-inflammatory diet increases levels of inflammatory cytokines such as TNF- $\alpha$ and IL-1, which may subsequently attract and induce migration of inflammatory cells into vascular tissues [176] or mediate adhesion of white blood cells to the vascular endothelium through increasing expression of cellular adhesion molecules such as cadherins [177].

\subsection{DII and MetS}

In the most recent meta-analysis conducted in 2018 [170], only five studies were included for DII vs. MetS relationship, three of which were of cross-sectional design. The overall pooled relative risk (1.01) was not significant (95\% CI: 0.82-1.24). However, in studies reporting null associations between DII vs. MetS, some have reported significant associations between DII and components of MetS (e.g., higher DII and lower high density lipoprotein cholesterol in a Polish-Norwegian study [177]), suggesting that different durations of pro-inflammatory exposure were needed for different MetS components [170]. Several studies have been published after the latest meta-analysis, all utilizing a cross-sectional design [41,178-180]. The results were again mixed, with three studies reporting higher odds of MetS comparing the highest vs. lowest quantiles of DII scores [8,41,179], while others reported no consistent associations $[178,180]$. Differences in study settings and participants' characteristics including age, sex, geographic location, and ethnic background, all potentially leading to differences in the variation of DII, might have explained the disparities in these results. Furthermore, most of these studies were cross-sectional in nature and thus temporality of effect cannot be established, thus limiting causal inference. More definitive results from high-quality prospective studies and trials are needed in this field.

\subsection{DII and Obesity}

In the sole meta-analysis appraising evidence for DII vs. obesity and BMI, a pro-inflammatory diet is associated with a higher risk of obesity (pooled odds ratio (OR): $1.31 ; 95 \% \mathrm{CI}: 1.14,1.50 ; \mathrm{n}=4$ studies) and mean BMI (mean difference: $0.81 \mathrm{~kg} / \mathrm{m}^{2} ; 95 \% \mathrm{CI}: 0.37,1.26 \mathrm{~kg} / \mathrm{m}^{2} ; \mathrm{n}=22$ studies) [169]. It is worth noting that there was an extremely high level of heterogeneity for the BMI meta-analysis $\left(I^{2}=94.7 \%\right)$, 
which was only partially explained by type of dietary assessment $\left(I^{2}=8.4 \%\right.$ in three studies using 24 -h recalls cf. $98.7 \%$ for 19 studies using food frequency questionnaires). Further, three out of four studies concerning obesity included only women, impacting on generalizability to the general population. It also is very challenging to elucidate the direction of causality between inflammation and increased adiposity, with most Mendelian randomization studies suggesting that inflammation is a consequence rather than a cause of obesity $[181,182]$. Since this meta-analysis, there have been a few more studies looking at this association; one was conducted in Pakistan where significant positive correlations were found between DII score and weight, BMI, waist-to-hip ratio, and body fat percentage [183] and another in Iran where a pro-inflammatory diet was associated with higher BMI z-score, wrist circumference, neck circumference, waist circumference, head circumference and parental BMI [184]. In a longitudinal study from Brazil, a pro-inflammatory diet at baseline was associated with smaller reductions in weight and body fat and poorer dietary quality (reduced consumption of fruits, vegetables, and legumes) six months after bariatric surgery [185]. Complicating this picture is the fact that pro-inflammatory foods tend to be calorically dense, and therefore likely to contribute directly to increased adiposity [15].

\subsection{DII and T2DM or Gestational Diabetes Mellitus (GDM)}

Only one study each has investigated the associations between DII and T2DM in general populations [186] or GDM during pregnancy [187]. High DII scores, indicating pro-inflammatory diets, were significantly associated with a higher risk of T2DM (adjusted OR $=3.02$ comparing extreme quintiles) and GDM (adjusted OR $=2.10$ comparing extreme tertiles). Another study examining pre-diabetes as the outcome found similar direction of association [188]. Nonetheless, the above-mentioned studies were of cross-sectional/case-control designs and were set in developing countries. High-quality, prospective evidence from other countries with different socioeconomic circumstances is needed. As comorbidities are an important part of population health in which T2DM figures prominently, it is important to note that we found that pro-inflammatory diet, as indicated by higher DII scores, was associated with increased risks of all-cause, CVD, all-cancer, and digestive-tract cancer mortality among pre-diabetic NHANES participants [90].

In summary, evidence to date suggests potential benefits of reducing dietary inflammation in lowering CVD risk and its associated mortality, while evidence for MetS, obesity, and diabetes is either conflicting or limited due largely to the paucity of studies, generally small sample sizes, variations in participants' characteristics such as sex and ethnic background, and the fact that the parameters that define MetS occur earlier in disease development. Further evidence, especially from high-quality prospective studies and carefully designed controlled trials are required before solid recommendations can be issued in the context of MetS, obesity, and diabetes.

\section{DII and Respiratory Health}

Growing evidence shows that exposure to an unhealthy diet (in utero and also later in life) might affect respiratory health throughout the life course $[189,190]$. It has been suggested that pro-inflammatory dietary components might lead to low-grade systemic inflammation, and subsequently, to airway inflammation thus influencing asthma development and severity [191,192]. Anti-inflammatory dietary components might have a protective effect on respiratory outcomes [193,194]. Studies on the associations of the inflammatory potential of the diet, as summarized by the DII score, with lung function and asthma are scarce and have been performed only in a cross-sectional setting. In adults, a small case-control study among subjects showed that 1 unit increase in the DII score was associated with a $70 \%$ higher risk of asthma and a $3.44 \%$ lower percent predicted Forced Expiratory Volume in $1 \mathrm{~s}\left(\mathrm{FEV}_{1}\right)$ [195]. Similarly, a recent large cohort study among more than 30,000 subjects found that only among adults without asthma or wheezing, a higher DII score was associated with a 0.22 and 0.35 lower percent predicted $\mathrm{FEV}_{1}$ and Forced Vital Capacity (FVC), respectively [196]. Furthermore, a higher DII score was associated with a higher risk of wheezing, but not with asthma [196]. In children, a pro-inflammatory diet was not associated with current asthma or lung function, but in children 
with allergic airway inflammation, a higher DII score was associated with a 2.38 fold higher risk of wheezing [196].

Although it has been hypothesized that fetal life is a critical period for respiratory health later in life, the programming effect of the maternal DII score in pregnancy on child's respiratory health has not yet been studied [197]. However, studies on the intake of single pro- or anti-inflammatory nutrients by the mother during pregnancy suggest potential effects of maternal nutrition on child's respiratory health [189]. The main pro-inflammatory components in the DII score are calorie-contributing nutrients including trans-fat, saturated fat, and cholesterol [27]. Previous studies observed inconclusive results for the association of maternal intake of these nutrients during pregnancy, as well as for the intake of a dietary pattern, which is rich in these fats, with child's wheezing or asthma [198-202]. Conversely, nutrients mainly derived from fruits and vegetables as well as n-3 fatty acids are the main anti-inflammatory components in the DII score [27]. Although total fruit and vegetable intake in pregnancy was not associated, higher consumption of apples, which are rich in flavonoids, seems associated with a lower risk of childhood wheeze and asthma [202,203]. Furthermore, a randomized controlled trial showed that children of mothers who received supplementation with n-3 long-chain polyunsaturated fatty acids in pregnancy had a risk reduction of $7 \%$ for persistent wheeze or asthma [204]. In addition, a higher DII score during pregnancy has been associated, independent of the pre-pregnancy BMI, with higher C-reactive protein levels, which reflect higher maternal systemic inflammation [205]. Higher C-reactive protein levels at birth, but not in early pregnancy, were previously associated with a higher risk of wheezing in pre-school children [206]. Thus, it might be that the inflammatory potential of maternal diet in pregnancy, through systemic inflammation, is a contributing factor to the development of childhood wheezing or asthma. However, the potential underlying mechanisms as well as the long-lasting effects of the inflammatory potential of the diet as summarized by the DII score in different stages of life warrants further investigation.

\section{DII and Neurodevelopment}

Child neurodevelopment is caused by a variety of phenomena, influenced by both genetic and environmental factors, as well as interactions between them [207]. The importance of adequate nutrition during fetal life and early childhood with respect to long-term neurodevelopment including cognitive functions, psychomotor abilities, intelligence, and behavior is of increasing interest [208]. It is well established that severe maternal malnutrition during pregnancy and severe deficiency of certain micronutrients can impair child neurodevelopment [209]. On the other hand, some nutrients can be toxic when consumed in excess. However, the impact of more subtle variations in maternal diet quality on child neurodevelopment has been less frequently evaluated. The majority of studies in this field have focused on selected nutritional factors (vitamins, minerals, essential elements, protein, and fatty acids) and not on a diet as a whole. For example, deficiencies in vitamins $\mathrm{A}$ and $\mathrm{D}$ have been associated with impaired learning and memory, as well as psychomotor and language abilities [209]. Deficiency in group B vitamins has been associated with neural tube defects, delayed language development and impaired motor functioning [209]. Micronutrients including iron, selenium, manganese, and zinc have been shown to have a neuroprotective effect [209-211].

Following general recommendations to focus on diet as whole, the meta-analysis by Borge et al. provides a quantitative summary of the existing literature (published between 2004 and 2016) exploring the relationship between maternal diet quality and child cognitive and affective outcomes [208,212-229]. The analyzed studies have focused on dietary patterns (most frequently defined as healthy and unhealthy), fish/seafood intake, omega-6/omega-3 fatty acid ratio, saturated fat intake, and dietary fiber, which have been assessed by the use of the food frequency questionnaire (FFQ) and a variety of neurodevelopmental outcomes (externalizing, internalizing, and socio-emotional, cognitive). Based on 18 studies comprising almost 64,000 participants, better maternal diet quality had a small but consistent association with all neurodevelopmental dimensions except for the internalizing dimension, with more reliable results observed for cognitive development. Maternal diet can be a 
marker for the child's diet (not systematically controlled for in the majority of the studies), which is a competing exposure that also influences child development. The analysis published by Malin et al. in 2018 also indicates that mothers who consumed more nutritious diets during pregnancy tended to have children with more favorable neurodevelopmental outcomes, while mothers who consumed less nutritious diets and/or higher levels of sodium, saturated fat, and/or sugar during pregnancy had children who tended to perform more poorly on memory, perceptual, and quantitative, verbal and motor tasks [230]. Furthermore, these associations, though similar, were weaker for the impact of childhood nutrition, which, as pointed out by those authors, could suggest that prenatal nutrition plays a greater role in neurodevelopment.

Evidence from human studies has confirmed what was observed in animal models showing that many nutrients are necessary for brain development. The effect of specific nutrients and their deficiency on the following neurodevelopmental processes has been described: neuron proliferation, axon and dendrite growth, synapse formation, pruning and function, myelination, and neuronal apoptosis. Inflammation has been increasingly recognized as an important contributor to central nervous system damage in both the developing child and adult brain. The brain is particularly vulnerable in utero as well as during infancy and early childhood, and insults occurring during these critical periods have the potential to cause long-term damage. Cells within the developing brain use cytokines for autocrine and paracrine signaling, and because many of these cytokines also coordinate the host immune response, normal cytokine-mediated developmental processes are susceptible to disruption by cytokine imbalances [231-237]. Pro-inflammatory cytokine induction has been shown to adversely affect neurodevelopment whereas anti-inflammatory or regulatory cytokines have been shown to diminish adverse effects. Some neurodevelopmental abnormalities including autism spectrum disorders (ASD) and cognitive impairment have been linked to early life immune activation and inflammation [231]. The DII has been associated with cognitive disorders such as Parkinson's disease [238,239] as well as normal cognitive decline in aging populations [238-243], but there is still a lack of research in relation to child neurodevelopment.

In summary, evidence to date suggests that a better maternal diet quality is associated with a more favorable cognitive development and fewer affective problems in the child.

\section{DII and Mental Health}

The rising prevalence of mental health disorders represents a major public health concern. Worldwide, the prevalence of depression is approximately 350 million [244] and the WHO estimates that more than one in four European adults have experienced a psychological disorder [245]. The Global Burden of Disease Study has highlighted the substantial contribution of adverse mental health to the global burden of NCDs, especially through years lived with disability [244]. Multifactorial processes including, amongst others, biological and environmental factors contribute to an individual's mental health and well-being [246]. Dietary patterns have been examined in this context. Unhealthy diets characterized by high intake of energy-dense, high-sugar and/or high-fat foods, processed and red meats, alcohol, and refined grains have been associated with increased risk of depression [247,248], whereas healthy diets characterized by a high consumption of fruit, vegetables, whole grains, fish, and lean meats have been linked with reduced depression risk [249,250].

Chronic low-grade inflammation also is associated with adverse mental health outcomes [251,252]. Three recent systematic reviews and meta-analyses have examined dietary quality, dietary patterns and dietary inflammation and depressive outcomes [253-255]. Based on observational studies adhering to healthy less pro-inflammatory diets appears to be associated with a lower risk of depression. In addition, two recent systematic reviews and a meta-analysis specifically on the DII and depression risk have been published [256,257]. In the systematic review, all but one of the 12 included studies demonstrated an association between dietary inflammation and increased risk of incident depression in adults [256]. The meta-analysis by Wang et al. examined four prospective and two cross-sectional studies ( $\mathrm{n}=49,584$ subjects). They report that individuals with the highest DII scores had a $23 \%$ greater 
risk of depression relative to those with the lowest DII scores. This association was gender specific, being observed in women only [257]. The DII also has been examined in severe mental illness. Using data from the UK Biobank study $(n=68,879)$ higher DII scores were observed among those with schizophrenia and major depressive disorder but not bipolar disorder, relative to the controls [258].

To date, most of the research examining the relationship between the DII and mental health has focused on depression and depressive symptoms; therefore, this review will focus on those conditions. In female-only studies increased risk of depressive symptoms in adolescents and depression in middle-aged women was observed among those with the most pro-inflammatory diets $[259,260]$. Gender differences also have been observed in both cross-sectional and longitudinal studies including male and female participants. Examination of prospective associations between the DII and incident depressive symptoms in the SU.VI.MAX (Supplémentation en Vitamines et Minéraux Antioxydants) cohort ( $\mathrm{n}=3523$, mean follow-up 12.6 years) revealed that men, but not women, with higher DII scores had a greater risk of incident depressive symptoms [261]. Further examination of subgroups revealed greater risk among smokers and those who are physically inactive, suggesting that promotion of a more anti-inflammatory diet could confer benefits for these groups. Phillips et al., reported higher risk of depressive symptoms and anxiety (OR 1.70, 95\% CI 1.23-2.35 and OR 1.60, 95\% CI 1.15-2.24) and lower likelihood of well-being (OR 0.62, 95\% CI 0.46-0.83) among adults in the Mitchelstown cohort $(n=2047)$ with the most pro-inflammatory diet (tertile 3 vs. tertile 1 of E-DII). When stratified by gender these associations were observed among the female participants only [262]. Furthermore, a more pro-inflammatory diet also has been linked with an increased risk of recurrent depressive symptoms in women, but not men, in the Whitehall II study [263]. No gender differences were noted in the examination of the Seguimiento Universidad de Navarra (SUN) cohort study ( $\mathrm{n}=15,093$ ). After a mean follow-up of 8.5 years depression risk was approximately 1.5 time greater among those in the highest quintile of DII [264], stronger associations were noted among those $>55$ years and those with cardiometabolic comorbidities. Conversely, examination of data from the NHANES 2007-2012 $(n=11,624)$ revealed that the association between dietary inflammation and depression was independent of CVD risk as determined by the Framingham risk score [172]. In a cohort of older American adults ( $n=3648$, mean age 60.6 years) those with the highest DII score (quartile 4 ) had $24 \%$ greater risk of developing depressive symptoms over an eight-year follow-up relative to those with the most anti-inflammatory diet [265].

In summary, the evidence to date suggests that a more pro-inflammatory diet is associated with greater risk of depressive symptoms and depression, particularly among women and certain subgroups such as smokers and more physically inactive individuals. Gender effects may be explained by the fact that more studies focus on women and women tend to have higher rates of depression than men $[266,267]$. Further evidence, especially from randomized controlled trials, of the benefits of a more anti-inflammatory diet in terms of reducing risk of developing depression or improving inflammatory status among individuals with depression is required.

\section{DII and Musculoskeletal Health}

Dietary components (including certain micronutrients, vitamins, polyphenols and polyunsaturated fatty acids) and dietary patterns such as the Mediterranean diet have been associated with bone health [268-271]. Inflammation is also thought to be involved in the development and progression of osteoarthritis, osteoporosis, and fractures [272-275]. Thus examination of DII in this context has been conducted with a view to improving our understanding of how diet-related inflammation may be related to musculoskeletal health and disease. Thus far, the DII has been examined in relation to risk of osteoporosis, fractures, and falls. As age and female hormonal status are key risk factors for osteoporosis, it is not surprising that much of the research to date has focused on older-aged cohorts and postmenopausal women.

The Women's Health Initiative cohort study, the largest US study of postmenopausal women's health has examined E-DII scores, bone mineral density (BMD), and fracture risk in 161,191 women. 
Those women with the most anti-inflammatory diets had the smallest BMD loss over 6 years. Stratified analysis revealed greater hip fracture risk but lower total fracture and lower-arm fracture risk among white women aged $<63$ years with a higher DII score [275]. Using data from the 4 th and 5th Korean National Health and Nutrition Examination Surveys (KNHANES, 2009-2011), Na et al. examined associations between DII score and BMD in 2778 postmenopausal women. They report increased risk of total femur osteopenia/osteoporosis among women with the highest DII score (OR 1.27; 95\% CI; 1.00-1.62 comparing top vs. bottom DII tertiles) [276]. Results from a small study in postmenopausal Iranian women $(n=160)$ also suggest that a pro-inflammatory DII score is a risk factor for lower lumbar spine BMD [277].

Studies examining both men and women also have been conducted. Examination of associations between DII score with BMD in the US NHANES participants during 2005-2010 ( $\mathrm{n}=18,318)$ revealed an inverse association between BMD in different sites with increasing DII scores, which also was related to increased fracture risk [278]. Veronese et al. conducted two separate investigations on DII and bone health $[279,280]$. The first of these examined 4358 North American adults (mean age 61.2 years) participating in the Osteoarthritis Initiative. Prevalence of experiencing radiographic symptomatic knee osteoarthritis was higher (35.4\%) among those with a more pro-inflammatory diet (DII quartile 4) relative to those with a more anti-inflammatory diet (DII quartile $1(24.0 \%)$ ). Furthermore, regression analyses, adjusted for potential confounders including age, sex, BMI, physical activity, race, tobacco use, education and income, demonstrated that risk of experiencing radiographic symptomatic knee osteoarthritis was 1.4 times greater among those with the highest DII scores (OR $1.40 ; 95 \%$ CI; 1.14-1.72) [279]. In a case-control study from China, the multivariable-adjusted ORs (95\% CIs) for hip fracture across quartiles of DII scores were 1 (reference), $1.42(1.01,1.99), 1.63(1.16,2.28)$, and $2.44(1.73,3.45)$ [281].

Gender-specific associations have been observed. Further examination of the Osteoarthritis Initiative participants (3648 adults, mean age 60.6 years) with/at risk of knee osteoarthritis revealed greater fracture risk among women with the highest DII score quintile during eight-year follow-up. No associations were observed in the entire sample or among the men [280]. Cervo et al., examined prospective associations between DII scores and bone health, sarcopenia-related outcomes, falls risk and incident fractures in Australian older adults $(n=1099$ aged 50-79 at baseline, with 5 year $(n=768)$ and 10 year $(n=566)$ follow-up). They report that among men a more pro-inflammatory diet was associated with lower hip and lumbar spine BMD and greater risk of fractures and falls over 10 years, whereas among women, a more pro-inflammatory diet was associated with greater lower limb muscle quality and reduced fracture risk [282].

Not all studies have reported positive associations between DII and bone health. The Brazilian Osteoporosis Study ( $\mathrm{n}=2269$ adults $\geq 40$ years old) failed to identify any link between DII scores and low-impact fractures [283]. In further work the relationship between DII scores and muscle mass and strength were examined in Chinese children $(n=466$, age six-nine years). The authors reported negative associations between DII and total body skeletal muscle mass, appendicular skeletal and lean mass, and no association with grip strength [284]. Potential mechanisms linking dietary inflammation with bone health have been suggested including immune dysregulation characterized by chronic inflammation, which may promote overactivation of osteoclasts, reduction in osteoblast activity, changes in the extra-cellular matrix driving cartilage loss, and joint degeneration [285-288].

In summary, to our knowledge no meta-analyses have been conducted on the DII and bone/musculoskeletal health to date. Examinations of the findings from individual observational and longitudinal cohort studies suggest an unfavorable influence of a pro-inflammatory diet on fracture risk, BMD and osteoporosis. However, some limitations can be identified including a focus on postmenopausal women and ageing cohorts, thereby limiting generalizability of the findings. Where both sexes have been examined the noted sex differences suggest that higher DII scores may be more detrimental to musculoskeletal health in older men. Our understanding of the mechanisms underlying the associations between the early environment and future bone health is evolving. It is 
possible that nutrients and dietary inflammation may have a direct effect on bone mineralization, for example, maternal pregnancy 25-hydroxyvitamin D concentration is associated with umbilical cord venous serum calcium concentration; expression of a calcium transporter in the placenta is positively associated with neonatal bone mass [289]. However, there is increasing evidence for indirect mechanisms, involving epigenetic signaling, for example perinatal methylation at the retinoid $X$ receptor alpha locus (a key part of vitamin D signalling) is reduced by maternal gestational vitamin $\mathrm{D}$ supplementation, and is associated with offspring bone mass $[290,291]$. Future work examining the relationship between early life or childhood dietary inflammation on future bone health could provide important insights.

\section{DII and Intergenerational Health}

Pregnancy normally induces an anti-inflammatory response profile, which is tightly regulated from conception to delivery [292]. There is, however, little evidence that such an anti-inflammatory immune switch occurring during pregnancy may attenuate obesity-driven inflammation. Rather, it has been suggested that dysregulated innate immune profiles could be involved in fetal programming caused by maternal obesity [293]. Indeed, obesity-induced maternal inflammation or meta-inflammation may have a direct effect on fetal development, provided that maternal-derived inflammatory components such as cytokines, activated immune cells, or maternal metabolites are transferred across the placenta into fetal circulation. Such maternal inflammation also could have indirect effects on the fetus by modulating placental capacity to transfer nutrients to the fetus [294]. Increased cytokine levels have been detected in the placenta and cord blood of babies born to obese mothers [295]. Thus, maternal meta-inflammation might cause altered metabolic health in the offspring either by direct transfer of cytokines to the fetus or by altering the placental nutrient flow [296] or via epigenetic mechanisms [297].

The Barker hypothesis proposes that maternal in utero and early-life nutrition may permanently impact offspring physiology and alter their health trajectory [298]. This impact may be intergenerational and may be mediated by epigenetic mechanisms. Maternal intra-uterine environment, through epigenetic modulation, has shown to be an important determinant of offspring metabolism and health outcomes [299]. In a recent Gambian study, women conceiving in the rainy season had higher plasma concentrations of folate, vitamin B-2, betaine, cysteine and lower concentrations of dimethylglycine, pyridoxal-5'-phosphate, and homocysteine. Furthermore, there were associations between maternal 1 -carbon biomarkers and offspring DNA methylation at metastable epialleles [300,301]. These findings led the authors to suggest that if underlying nutritional status acts as an effect modifier for DNA methylation, then this would be applicable to populations with differing dietary patterns. In this context, maternal dietary inflammatory potential could also have its place within the potential physiological mechanisms explaining early nutritional programming of offspring birth outcomes and later health and disease.

Thus far, limited investigation of maternal DII or its potential influence on offspring epigenetics, birth outcomes or childhood health has been conducted and results are conflicting. Two separate investigations of Project Viva, a cohort consisting of mother-child pairs, revealed that a more pro-inflammatory diet during pregnancy was associated with maternal systemic inflammation, lower birth weight for gestational age, and infant adiposity [204,302]. The Healthy Start Study ( $\mathrm{n}=1078$ mother-neonate pairs) reported that higher DII scores in obese, but not lean or overweight, mothers were associated with increased neonatal adiposity [303]. The Newborn Epigenetic Study (NEST) cohort ( $n=1057$ mother-child pairs) examined associations between maternal E-DII during pregnancy and offspring birth outcomes. Further analysis of subsets included methylation of differentially methylated regions of imprinted genes involved in fetal growth and development $(n=338)$ and maternal cytokines $(n=105)$. While no associations between maternal E-DII and offspring birth weight, methylation, or maternal cytokines were found, higher E-DII scores were associated with greater risk of pre-term birth of female offspring and with cesarean delivery for women with a BMI in the obese range [304]. 
Ethnic diversity, use of either the DII and E-DII, and maternal weight status during pregnancy may contribute to the disparity between studies.

In summary, a large body of evidence, particularly from animal studies, shows that food components have the ability to modulate epigenetic markers both directly and indirectly through the in utero environment from mother to offspring [299]. While selected micronutrients or food components have been examined in human studies, there is a lack of research on dietary patterns and specifically the DII. Thus, further investigation regarding the potential influence of early life exposure to a pro-inflammatory environment on long-term and intergenerational health and disease is necessary.

\section{Conclusions and Future Directions}

In this review, we examined and synthesized findings from a very large and rapidly growing body of research investigating associations between dietary inflammatory potential, determined by the DII, and NCD risk. The evidence suggests that a more pro-inflammatory diet in adults is associated with increased risk of certain cancers, CVD and its associated mortality, adverse mental health, and musculoskeletal disorders. Overall, results support a role for dietary inflammation in the pathophysiology of these conditions. These findings highlight the potential benefits of transitioning to a more anti-inflammatory/less pro-inflammatory diet to decrease disease risk. The evidence regarding DII and respiratory health, neurodevelopmental outcomes, MetS, obesity and diabetes is either conflicting or limited. Thus future research investigating the potential influence of dietary inflammatory status on these conditions is warranted. Limitations of the evidence are that it is based mostly on observational studies so causality cannot be firmly established because the temporality criterion of the Criteria for Judging Causality is often not satisfied $[305,306]$. Future studies, including adaptive/pragmatic and randomized controlled trials $[307,308]$, are required to provide additional evidence. The evidence of positive associations across a wide array of studies examining different outcomes in diverse populations indicates that the computation of the DII/ E-DII is robust with respect to dietary assessment, especially different FFQs.

The recent development and validation of the children's DII (C-DII) presents new opportunities to investigate similar diet-health relationships in childhood. Such studies may provide important insights, particularly from developmental origins of health and disease perspective. Given that early-life nutritional exposure may exert effects on long term health and that these effects may also be intergenerational, we eagerly await the findings of the ALPHABET study ("Early life programming of childhood health: a nutritional and epigenetic investigation of adiposity and bone, cardiometabolic, neurodevelopmental and respiratory health"), which is investigating early-life nutritional programming of childhood health. The ALPHABET consortium consisting of several European birth cohorts $(>65,000$ participants) [309-315] is specifically examining maternal DII during pregnancy and associations with offspring birth outcomes, childhood health outcomes including adiposity and bone, cardiometabolic, neurodevelopmental and respiratory health, and epigenetics. Improving our understanding of nutritional programming of childhood health may help inform development of more effective evidence-based public health strategies for example, with an emphasis on advocating a healthy anti-inflammatory diet in pre-pregnancy, pregnancy and early postnatal life, to improve both mother and offspring health and attenuate development of adverse health outcomes over the life course and potentially in future generations. It is important to note that diet is only part of the equation and other lifestyle factors especially sedentary behavior and physical activity play key roles in modulating inflammation and health. Thus more holistic assessment of healthy lifestyle behaviors, including dietary inflammation, may inform the development of more effective healthy lifestyle interventions, which may open up new avenues of investigation.

Author Contributions: All authors contributed substantially to this review: conceptualization: C.M.P.; writing original draft preparation: C.M.P.; L.-W.C.; B.H.; J.Y.B.; N.C.H.; L.D.; S.M.M.-B.; K.P.; G.M.; M.S.; N.S., J.R.H.; manuscript review and editing of final draft: C.M.P.; L.-W.C.; B.H.; J.Y.B.; N.C.H.; L.D.; S.M.M.-B.; K.P.; G.M.; M.S.; N.S., J.R.H. 
Funding: This work was supported by an award from the European Union's Horizon 2020 research and innovation programme under the ERA-Net Cofund of the Joint Programming Initiative Healthy Diet for Healthy Life (JPI-HDHL) (http://www.healthydietforhealthylife.eu) action number 696295 (Biomarkers for Nutrition and Health). Co-funding was provided by Science Foundation Ireland, Ireland (Grant Number SFI/16/ERA-HDHL/3360), the UK Biotechnology and Biological Sciences Research Council (ERA-HDHL Biomarkers: BBSRC: BB/P028179/1 and BB/P028187/1), the Polish National Centre for Research and Development (ERA-HDHL/01/ALPHABET/1/2017), the ZonMW The Netherlands (no 529051014; 2017)) ALPHABET project (no 696295; 2017) and the French National Agency of Research (reference AnrR16227KK). Funding was also provided by a research grant from the Irish Health Research Board (reference HRC/2007/13). The funders had no role in the design of the study; in the collection, analyses, or interpretation of data; in the writing of the manuscript, or in the decision to publish the results.

Conflicts of Interest: James R. Hébert owns controlling interest in Connecting Health Innovations LLC (CHI), a company that has licensed the right to his invention of the dietary inflammatory index (DII $\left.{ }^{\circledR}\right)$ from the University of South Carolina in order to develop computer and smart phone applications for patient counseling and dietary intervention in clinical settings. Nitin Shivappa is an employee of CHI.

\section{References}

1. GBD 2016 Causes of Death Collaborators. Global, regional, and national age-sex specific mortality for 264 causes of death, 1980-2016: A systematic analysis for the Global Burden of Disease Study 2016. Lancet 2017, 390, 1151-1210. [CrossRef]

2. Bennett, J.M.; Reeves, G.; Billman, G.E.; Sturmberg, J.P. Inflammation-Nature's Way to Efficiently Respond to All Types of Challenges: Implications for Understanding and Managing "the Epidemic" of Chronic Diseases. Front. Med. 2018, 5, 316. [CrossRef] [PubMed]

3. Calder, P.C.; Bosco, N.; Bourdet-Sicard, R.; Capuron, L.; Delzenne, N.; Doré, J.; Franceschi, C.; Lehtinen, M.J.; Recker, T.; Salvioli, S.; et al. Health relevance of the modification of low grade inflammation in ageing (inflammageing) and the role of nutrition. Ageing Res. Rev. 2017, 40, 95-119. [CrossRef] [PubMed]

4. Hotamisligil, G.S. Inflammation, metaflammation and immunometabolic disorders. Nature 2017, 542, 177-185. [CrossRef] [PubMed]

5. Micha, R.; Kalantarian, S.; Wirojratana, P.; Byers, T.; Danaei, G.; Elmadfa, I.; Ding, E.; Giovannucci, E.; Powles, J.; Smith-Warner, S.; et al. Estimating the global and regional burden of suboptimal nutrition on chronic disease: Methods and inputs to the analysis. Eur. J. Clin. Nutr. 2012, 66, 119-129. [CrossRef] [PubMed]

6. Willett, W.C.; Stampfer, M.J. Current evidence on healthy eating. Annu. Rev. Public Health 2013, 34, 77-95. [CrossRef]

7. Garcia-Arellano, A.; Martinez-Gonzalez, M.A.; Ramallal, R.; Salas-Salvadó, J.; Hebert, J.R.; Corella, D.; Shivappa, N.; Forga, L.; Muñoz-Bravo, C.; Estruch, R.; et al. Dietary inflammatory index and all-cause mortality in large cohorts: The SUN and PREDIMED studies. Clin. Nutr. 2019, 38, 1221-1231. [CrossRef]

8. Mazidi, M.; Shivappa, N.; Wirth, M.D.; Hebert, J.R.; Mikhailidis, D.P.; Kengne, A.P.; Banach, M. Dietary inflammatory index and cardiometabolic risk in US adults. Atherosclerosis 2018, 276, 23-27. [CrossRef]

9. Park, S.-Y.; Kang, M.; Wilkens, L.R.; Shvetsov, Y.B.; Harmon, B.E.; Shivappa, N.; Wirth, M.D.; Hébert, J.R.; Haiman, C.A.; Le Marchand, L.; et al. The Dietary Inflammatory Index and All-Cause, Cardiovascular Disease, and Cancer Mortality in the Multiethnic Cohort Study. Nutrients 2018, 10, 1844. [CrossRef]

10. Shivappa, N.; Godos, J.; Hébert, J.R.; Wirth, M.D.; Piuri, G.; Speciani, A.F.; Grosso, G. Dietary Inflammatory Index and Colorectal Cancer Risk-A Meta-Analysis. Nutrients 2017, 9, 1043. [CrossRef]

11. Shivappa, N.; Godos, J.; Hébert, J.R.; Wirth, M.D.; Piuri, G.; Speciani, A.F.; Grosso, G. Dietary Inflammatory Index and Cardiovascular Risk and Mortality-A Meta-Analysis. Nutrients 2018, 10, 200. [CrossRef]

12. Shivappa, N.; Schneider, A.; Hebert, J.R.; Koenig, W.; Peters, A.; Thorand, B. Association between dietary inflammatory index, and cause-specific mortality in the MONICA/KORA Augsburg Cohort Study. Eur. J. Public Health 2018, 28, 167-172. [CrossRef]

13. Imamura, F.; Micha, R.; Khatibzadeh, S.; Fahimi, S.; Shi, P.; Powles, J.; Mozaffarian, D. Dietary quality among men and women in 187 countries in 1990 and 2010: A systematic assessment. Lancet Glob. Health 2015, 3, e132-e142. [CrossRef]

14. Minihane, A.M.; Vinoy, S.; Russell, W.R.; Baka, A.; Roche, H.M.; Tuohy, K.M.; Teeling, J.L.; Blaak, E.E.; Fenech, M.; Vauzour, D.; et al. Low-grade inflammation, diet composition and health: Current research evidence and its translation. Br. J. Nutr. 2015, 114, 999-1012. [CrossRef] 
15. Hebert, J.R.; Shivappa, N.; Wirth, M.D.; Hussey, J.R.; Hurley, T.G. Perspective: The Dietary Inflammatory Index (DII)-Lessons Learned, Improvements Made, and Future Directions. Adv. Nutr. 2019, 10, 185-195. [CrossRef]

16. Tyson, C.C.; Nwankwo, C.; Lin, P.-H.; Svetkey, L.P. The Dietary Approaches to Stop Hypertension (DASH) Eating Pattern in Special Populations. Curr. Hypertens. Rep. 2012, 14, 388-396. [CrossRef]

17. Heroux, M.; Janssen, I.; Lam, M.; Lee, D.-C.; Hebert, J.R.; Sui, X.; Blair, S.N. Dietary patterns and the risk of mortality: Impact of cardiorespiratory fitness. Int. J. Epidemiol. 2010, 39, 197-209. [CrossRef]

18. Wirth, M.D.; Hebert, J.R.; Shivappa, N.; Hand, G.A.; Hurley, T.G.; Drenowatz, C.; McMahon, D.; Shook, R.P.; Blair, S.N. Anti-inflammatory Dietary Inflammatory Index scores are associated with healthier scores on other dietary indices. Nutr. Res. 2016, 36, 214-219. [CrossRef]

19. Dugué, P.-A.; Hodge, A.M.; Brinkman, M.T.; Bassett, J.K.; Shivappa, N.; Hebert, J.R.; Hopper, J.L.; English, D.R.; Milne, R.L.; Giles, G.G. Association between selected dietary scores and the risk of urothelial cell carcinoma: A prospective cohort study. Int. J. Cancer 2016, 139, 1251-1260. [CrossRef]

20. Van Horn, L.; Appel, L.J. Did the PREDIMED Trial Test a Mediterranean Diet? N. Engl. J. Med. 2013, 368, 1353-1354.

21. Buckland, G.; Travier, N.; Cottet, V.; Gonzalez, C.A.; Lujan-Barroso, L.; Agudo, A.; Trichopoulou, A.; Lagiou, P.; Trichopoulos, D.; Peeters, P.H.; et al. Adherence to the mediterranean diet and risk of breast cancer in the European prospective investigation into cancer and nutrition cohort study. Int. J. Cancer 2013, 132, 2918-2927. [CrossRef]

22. Viscogliosi, G.; Cipriani, E.; Liguori, M.L.; Marigliano, B.; Saliola, M.; Ettorre, E.; Andreozzi, P. Mediterranean Dietary Pattern Adherence: Associations with Prediabetes, Metabolic Syndrome, and Related Microinflammation. Metab. Syndr. Relat. Disord. 2013, 11, 210-216. [CrossRef]

23. Tseng, M.; Vierkant, R.A.; Kushi, L.H.; Sellers, T.A.; Vachon, C.M. Dietary patterns and breast density in the Minnesota Breast Cancer Family Study. Cancer Causes Control 2008, 19, 481-489. [CrossRef]

24. Lucas, M.; Chocano-Bedoya, P.; Schulze, M.B.; Mirzaei, F.; O’Reilly, E.J.; Okereke, O.I.; Hu, F.B.; Willett, W.C.; Ascherio, A. Inflammatory dietary pattern and risk of depression among women. Brain Behav. Immun. 2014, 36, 46-53. [CrossRef]

25. Tabung, F.K.; Smith-Warner, S.A.; Chavarro, J.E.; Wu, K.; Fuchs, C.S.; Hu, F.B.; Chan, A.T.; Willett, W.C.; Giovannucci, E.L. Development and Validation of an Empirical Dietary Inflammatory Index. J. Nutr. 2016, 146, 1560-1570. [CrossRef]

26. Cavicchia, P.P.; Steck, S.E.; Hurley, T.G.; Hussey, J.R.; Ma, Y.; Ockene, I.S.; Hébert, J.R. A New Dietary Inflammatory Index Predicts Interval Changes in Serum High-Sensitivity C-Reactive Protein. J. Nutr. 2009, 139, 2365-2372. [CrossRef]

27. Shivappa, N.; Steck, S.E.; Hurley, T.G.; Hussey, J.R.; Hebert, J.R. Designing and developing a literature-derived population-based dietary inflammatory index. Public Health Nutr. 2014, 17, 1689-1696. [CrossRef]

28. Hebert, J.R.; Ockene, I.S.; Hurley, T.G.; Luippold, R.; Well, A.D.; Harmatz, M.G. Development and testing of a seven-day dietary recall. J. Clin. Epidemiol. 1997, 50, 925-937. [CrossRef]

29. Shivappa, N.; Steck, S.E.; Hurley, T.G.; Hussey, J.R.; Ma, Y.; Ockene, I.S.; Tabung, F.; Hébert, J.R. A population-based dietary inflammatory index predicts levels of c-reactive protein (CRP) in the SEASONS Study. Public Health Nutr. 2014, 17, 1825-1833. [CrossRef]

30. Wirth, M.D.; Burch, J.; Shivappa, N.; Violanti, J.M.; Burchfiel, C.M.; Fekedulegn, D.; Andrew, M.E.; Hartley, T.A.; Miller, D.B.; Mnatsakanova, A.; et al. Association of a Dietary Inflammatory Index with Inflammatory Indices and the Metabolic Syndrome among Police Officers. J. Occup. Environ. Med. 2014, 56, 986-989. [CrossRef]

31. Shivappa, N.; Hebert, J.R.; Rietzschel, E.R.; De Buyzere, M.L.; Langlois, M.; Debruyne, E.; Marcos, A.; Huybrechts, I. Associations between dietary inflammatory index and inflammatory markers in the Asklepios Study. Br. J. Nutr. 2015, 113, 665-671. [CrossRef]

32. Tabung, F.K.; Steck, S.E.; Zhang, J.; Ma, Y.; Liese, A.D.; Agalliu, I.; Hingle, M.; Hou, L.; Hurley, T.G.; Jiao, L.; et al. Construct Validation of the Dietary Inflammatory Index among Postmenopausal Women. Ann. Epidemiol. 2015, 25, 398-405. [CrossRef]

33. Shivappa, N.; Hebert, J.R.; Marcos, A.; Diaz, L.-E.; Gomez, S.; Nova, E.; Michels, N.; Arouca, A.; González-Gil, E.; Frederic, G.; et al. Association between dietary inflammatory index and inflammatory markers in the HELENA study. Mol. Nutr. Food Res. 2017, 61, 1600707. [CrossRef] 
34. Shivappa, N.; Wirth, M.D.; Hurley, T.G.; Hebert, J.R. Association between the Dietary Inflammatory Index (DII) and telomere length and C-reactive protein from the National Health and Nutrition Examination Survey 1999-2002. Mol. Nutr. Food Res. 2016, 61. [CrossRef]

35. Julia, C.; Assmann, K.E.; Shivappa, N.; Hebert, J.R.; Wirth, M.D.; Hercberg, S.; Touvier, M.; Kesse-Guyot, E. Long-term associations between inflammatory dietary scores in relation to long-term C-reactive protein status measured 12 years later: Findings from the Supplémentation en Vitamines et Minéraux Antioxydants (SU.VI.MAX) cohort. Br. J. Nutr. 2017, 117, 306-314. [CrossRef]

36. Vahid, F.; Shivappa, N.; Hekmatdoost, A.; Hebert, J.R.; Davoodi, S.H.; Sadeghi, M. Association between Maternal Dietary Inflammatory Index (DII) and abortion in Iranian women and validation of DII with serum concentration of inflammatory factors: Case-control study. Appl. Physiol. Nutr. Metab. 2017, 42, 511-516. [CrossRef]

37. Wirth, M.D.; Shivappa, N.; Davis, L.; Hurley, T.G.; Ortaglia, A.; Drayton, R.; Blair, S.N.; Hébert, J.R. Construct validation of the Dietary Inflammatory Index among African Americans. J. Nutr. Health Aging 2017, 21, 487-491. [CrossRef]

38. Vahid, F.; Shivappa, N.; Faghfoori, Z.; Khodabakhshi, A.; Zayeri, F.; Hebert, J.R.; Davoodi, S.H. Validation of a Dietary Inflammatory Index (DII) and Association with Risk of Gastric Cancer: A Case-Control Study. Asian Pac. J. Cancer Prev. 2018, 19, 1471-1477.

39. Shivappa, N.; Wirth, M.D.; Murphy, E.A.; Hurley, T.G.; Hebert, J.R. Association between the Dietary Inflammatory Index (DII) and urinary enterolignans and C-reactive protein from the National Health and Nutrition Examination Survey 2003-2008. Eur. J. Nutr. 2018, 58, 797-805. [CrossRef]

40. Bodén, S.; Wennberg, M.; Van Guelpen, B.; Johansson, I.; Lindahl, B.; Andersson, J.; Shivappa, N.; Hebert, J.R.; Nilsson, L.M. Dietary inflammatory index and risk of first myocardial infarction; A prospective population-based study. Nutr. J. 2017, 16, 800. [CrossRef]

41. Phillips, C.M.; Shivappa, N.; Hébert, J.R.; Perry, I.J. Dietary Inflammatory Index and Biomarkers of Lipoprotein Metabolism, Inflammation and Glucose Homeostasis in Adults. Nutrients 2018, 10, 1033. [CrossRef]

42. Tabung, F.K.; Steck, S.E.; Ma, Y.; Liese, A.D.; Zhang, J.; Caan, B.; Hou, L.; Johnson, K.C.; Mossavar-Rahmani, Y.; Shivappa, N.; et al. The association between dietary inflammatory index and risk of colorectal cancer among postmenopausal women: Results from the Women's Health Initiative. Cancer Causes Control 2015, 26, 399-408. [CrossRef]

43. Kizil, M.; Tengilimoglu-Metin, M.M.; Gumus, D.; Sevim, S.; Turkoglu, I.; Mandiroglu, F. Dietary inflammatory index is associated with serum C-reactive protein and protein energy wasting in hemodialysis patients: A cross-sectional study. Nutr. Res. Pract. 2016, 10, 404-410. [CrossRef]

44. Kotemori, A.; Sawada, N.; Iwasaki, M.; Yamaji, T.; Shivappa, N.; Hebert, J. Association between dietary inflammatory index and high-sensitive C-reactive protein levels in cancer screening in Japanese. Rev. D'Epidemiol. St. Publique 2018, 66, S347. [CrossRef]

45. Shin, D.; Lee, K.W.; Brann, L.; Shivappa, N.; Hebert, J.R. Dietary inflammatory index is positively associated with serum high-sensitivity C-reactive protein in a Korean adult population. Nutrition 2018, 63-64, 155-161. [CrossRef]

46. Mirmajidi, S.; Izadi, A.; Saghafi-Asl, M.; Vahid, F.; Karamzad, N.; Amiri, P.; Shivappa, N.; Hébert, J.R. Inflammatory Potential of Diet: Association With Chemerin, Omentin, Lipopolysaccharide-Binding Protein, and Insulin Resistance in the Apparently Healthy Obese. J. Am. Coll. Nutr. 2019, 38, 302-310. [CrossRef]

47. Wirth, M.D.; Sevoyan, M.; Hofseth, L.; Shivappa, N.; Hurley, T.G.; Hébert, J.R. The Dietary Inflammatory Index is associated with elevated white blood cell counts in the National Health and Nutrition Examination Survey. Brain Behav. Immun. 2018, 69, 296-303. [CrossRef]

48. Shivappa, N.; Bonaccio, M.; Hebert, J.R.; Di Castelnuovo, A.; Costanzo, S.; Ruggiero, E.; Pounis, G.; Donati, M.B.; de Gaetano, G.; Iacoviello, L.; et al. Association of proinflammatory diet with low-grade inflammation: Results from the Moli-sani study. Nutrition 2018, 54, 182-188. [CrossRef]

49. Khan, S.; Wirth, M.D.; Ortaglia, A.; Alvarado, C.R.; Shivappa, N.; Hurley, T.G.; Hebert, J.R. Design, Development and Construct Validation of the Children's Dietary Inflammatory Index. Nutrients 2018, 10, 993. [CrossRef]

50. Balkwill, F.; Mantovani, A. Inflammation and cancer: Back to Virchow? Lancet 2001, 357, 539-545. [CrossRef]

51. Li, D.; Hao, X.; Li, J.; Wu, Z.; Chen, S.; Lin, J.; Li, X.; Dong, Y.; Na, Z.; Zhang, Y.; et al. Dose-response relation between dietary inflammatory index and human cancer risk: Evidence from 44 epidemiologic studies involving 1,082,092 participants. Am. J. Clin. Nutr. 2018, 107, 371-388. [CrossRef] 
52. Lu, D.-L.; Ren, Z.-J.; Zhang, Q.; Ren, P.-W.; Yang, B.; Liu, L.-R.; Dong, Q. Meta-analysis of the association between the inflammatory potential of diet and urologic cancer risk. PLoS ONE 2018, 13, e0204845. [CrossRef]

53. Wang, L.; Liu, C.; Zhou, C.; Zhuang, J.; Tang, S.; Yu, J.; Tian, J.; Feng, F.; Liu, L.; Zhang, T.; et al. Meta-analysis of the association between the dietary inflammatory index (DII) and breast cancer risk. Eur. J. Clin. Nutr. 2018, 73, 509-517. [CrossRef]

54. Liu, Z.-Y.; Gao, X.-P.; Zhu, S.; Liu, Y.-H.; Wang, L.-J.; Jing, C.-X.; Zeng, F.-F. Dietary inflammatory index and risk of gynecological cancers: A systematic review and meta-analysis of observational studies. J. Gynecol. Oncol. 2019, 30, e23. [CrossRef]

55. Sawa, T.; Ohshima, H. Nitrative DNA damage in inflammation and its possible role in carcinogenesis. Nitric Oxide 2006, 14, 91-100. [CrossRef]

56. Sohn, J.J.; Schetter, A.J.; Yfantis, H.G.; Ridnour, L.A.; Horikawa, I.; Khan, M.A.; Robles, A.I.; Hussain, S.P.; Goto, A.; Bowman, E.D.; et al. Macrophages, Nitric Oxide and microRNAs Are Associated with DNA Damage Response Pathway and Senescence in Inflammatory Bowel Disease. PLoS ONE 2012, 7, e44156. [CrossRef]

57. Ohnishi, S.; Ma, N.; Thanan, R.; Pinlaor, S.; Hammam, O.; Murata, M.; Kawanishi, S. DNA Damage in Inflammation-Related Carcinogenesis and Cancer Stem Cells. Oxidative Med. Cell. Longev. 2013, 2013, 1-9. [CrossRef]

58. Brouwer, J.G.; Makama, M.; Van Woudenbergh, G.J.; Vasen, H.F.; Nagengast, F.M.; Kleibeuker, J.H.; Kampman, E.; Van Duijnhoven, F.J. Inflammatory potential of the diet and colorectal tumor risk in persons with Lynch syndrome. Am. J. Clin. Nutr. 2017, 106, ajcn152900. [CrossRef]

59. Murata, M. Inflammation and cancer. Environ. Health Prev. Med. 2018, 23, 50. [CrossRef]

60. Kawanishi, S.; Hiraku, Y.; Pinlaor, S.; Ma, N. Oxidative and nitrative DNA damage in animals and patients with inflammatory diseases in relation to inflammation-related carcinogenesis. Boil. Chem. 2006, 387, 365-372. [CrossRef]

61. Hussain, S.P.; Hofseth, L.J.; Harris, C.C. Radical causes of cancer. Nat. Rev. Cancer 2003, 3, 276-285. [CrossRef]

62. Philip, M.; Rowley, D.A.; Schreiber, H. Inflammation as a tumor promoter in cancer induction. Semin. Cancer Boil. 2004, 14, 433-439. [CrossRef]

63. Mann, J.R.; Backlund, M.G.; DuBois, R.N. Mechanisms of disease: Inflammatory mediators and cancer prevention. Nat. Clin. Pract. Oncol. 2005, 2, 202-210. [CrossRef]

64. Pan, M.-H.; Lai, C.-S.; Dushenkov, S.; Ho, C.-T.; Dushenkov, V. Modulation of Inflammatory Genes by Natural Dietary Bioactive Compounds. J. Agric. Food Chem. 2009, 57, 4467-4477. [CrossRef]

65. Guffey, C.R.; Fan, D.; Singh, U.P.; Murphy, E.A. Linking obesity to colorectal cancer: Recent insights into plausible biological mechanisms. Curr. Opin. Clin. Nutr. Metab. Care 2013, 16, 595-600. [CrossRef]

66. Zhang, M.; Zhou, S.; Zhang, L.; Ye, W.; Wen, Q.; Wang, J. Role of cancer-related inflammation in esophageal cancer. Crit. Rev. Eukaryot. Gene Expr. 2013, 23, 27-35. [CrossRef]

67. Sugase, T.; Takahashi, T.; Serada, S.; Nakatsuka, R.; Fujimoto, M.; Ohkawara, T.; Hara, H.; Nishigaki, T.; Tanaka, K.; Miyazaki, Y.; et al. Suppressor of cytokine signaling-1 gene therapy induces potent antitumor effect in patient-derived esophageal squamous cell carcinoma xenograft mice. Int. J. Cancer 2017, 140, 2608-2621. [CrossRef]

68. Mohseni, R.; Abbasi, S.; Mohseni, F.; Rahimi, F.; Alizadeh, S. Association between Dietary Inflammatory Index and the Risk of Prostate Cancer: A Meta-Analysis. Nutr. Cancer 2018, 71, 359-366. [CrossRef]

69. Moradi, S.; Issah, A.; Mohammadi, H.; Mirzaei, K. Associations between dietary inflammatory index and incidence of breast and prostate cancer: A systematic review and meta-analysis. Nutrients 2018, 56, 168-178. [CrossRef]

70. Namazi, N.; Larijani, B.; Azadbakht, L. Association between the dietary inflammatory index and the incidence of cancer: A systematic review and meta-analysis of prospective studies. Public Health 2018, 164, 148-156. [CrossRef]

71. Rhodes, J.M.; Campbell, B.J. Inflammation and colorectal cancer: IBD-associated and sporadic cancer compared. Trends Mol. Med. 2002, 8, 10-16. [CrossRef]

72. Toriola, A.T.; Cheng, T.Y.; Neuhouser, M.L.; Wener, M.H.; Zheng, Y.; Brown, E.; Miller, J.W.; Song, X.; Beresford, S.A.; Gunter, M.J.; et al. Biomarkers of inflammation are associated with colorectal cancer risk in women but are not suitable as early detection markers. Int. J. Cancer 2013, 132, 2648-2658. [CrossRef] 
73. Dubois, R.N. Role of Inflammation and Inflammatory Mediators in Colorectal Cancer. Trans. Am. Clin. Clim. Assoc. 2014, 125, 358-373.

74. Poullis, A.; Foster, R.; Shetty, A.; Fagerhol, M.K.; Mendall, M.A. Bowel Inflammation as Measured by Fecal Calprotectin: A Link between Lifestyle Factors and Colorectal Cancer Risk. Cancer Epidemiol. Biomark. Prev. 2004, 13, 279-284. [CrossRef]

75. Dales, L.G.; Friedman, G.D.; Ury, H.K.; Grossman, S.; Williams, S.R. A case-control study of relationships of diet and other traits to colorectal cancer in american blacks. Am. J. Epidemiol. 1979, 109, 132-144. [CrossRef]

76. Trichopoulos, D.; Polychronopoulou, A. Epidemiology, diet and colorectal cancer. Eur. J. Cancer Clin. Oncol. 1986, 22, 335-337. [CrossRef]

77. Wargovich, M.J.; Baer, A.R.; Hu, P.J.; Sumiyoshi, H. Dietary factors and colorectal cancer. Gastroenterol. Clin. N. Am. 1988, 17, 727-745.

78. Accardi, G.; Shivappa, N.; Di Maso, M.; Hebert, J.R.; Fratino, L.; Montella, M.; La Vecchia, C.; Caruso, C.; Serraino, D.; Libra, M.; et al. Dietary inflammatory index and cancer risk in the elderly: A pooled-analysis of Italian case-control studies. Nutrition 2019, 63-64, 205-210. [CrossRef]

79. Harmon, B.E.; Wirth, M.D.; Boushey, C.J.; Wilkens, L.R.; Draluck, E.; Shivappa, N.; Steck, S.E.; Hofseth, L.; Haiman, C.A.; Le Marchand, L.; et al. The Dietary Inflammatory Index Is Associated with Colorectal Cancer Risk in the Multiethnic Cohort. J. Nutr. 2017, 147, 430-438. [CrossRef]

80. Niclis, C.; Pou, S.A.; Shivappa, N.; Hébert, J.R.; Steck, S.E.; Díaz, M.D.P. Proinflammatory Dietary Intake is Associated with Increased Risk of Colorectal Cancer: Results of a Case-Control Study in Argentina Using a Multilevel Modeling Approach. Nutr. Cancer 2017, 70, 1-8. [CrossRef]

81. Obón-Santacana, M.; Romaguera, D.; Gracia-Lavedan, E.; Molinuevo, A.; Molina-Montes, E.; Shivappa, N.; Hebert, J.R.; Tardón, A.; Castaño-Vinyals, G.; Moratalla, F.; et al. Dietary Inflammatory Index, Dietary Non-Enzymatic Antioxidant Capacity, and Colorectal and Breast Cancer Risk (MCC-Spain Study). Nutrients 2019, 11, 1406. [CrossRef]

82. Rafiee, P.; Shivappa, N.; Hébert, J.R.; Nasab, S.J.; Bahrami, A.; Hekmatdoost, A.; Rashidkhani, B.; Sadeghi, A.; Houshyari, M.; Hejazi, E. Dietary Inflammatory Index and Odds of Colorectal Cancer and Colorectal Adenomatous Polyps in a Case-Control Study from Iran. Nutrients 2019, 11, 1213. [CrossRef]

83. Sharma, I.; Zhu, Y.; Woodrow, J.R.; Mulay, S.; Parfrey, P.S.; McLaughlin, J.R.; Hebert, J.R.; Shivappa, N.; Li, Y.; Zhou, X.; et al. Inflammatory diet and risk for colorectal cancer: A population-based case-control study in Newfoundland, Canada. Nutrition 2017, 42, 69-74. [CrossRef]

84. Shivappa, N.; Prizment, A.E.; Blair, C.K.; Jacobs, D.R.; Steck, S.E.; Hébert, J.R. Dietary Inflammatory Index (DII) and risk of colorectal cancer in Iowa Women's Health Study. Cancer Epidemiol. Biomark. Prev. 2014, 23, 2383-2392. [CrossRef]

85. Shivappa, N.; Zucchetto, A.; Montella, M.; Serraino, D.; Steck, S.E.; La Vecchia, C.; Hebert, J.R. Inflammatory potential of diet and risk of colorectal cancer: A case-control study from Italy. Br. J. Nutr. 2015, 114, 152-158. [CrossRef]

86. Shivappa, N.; Steck, S.E.; Shehadah, I.; Al-Jaberi, T.; Al-Nusairr, M.; Heath, D.; Hébert, J.R.; Hofseth, L.J.; Bani-Hani, K.E.; Tayyem, R. Dietary inflammatory index and odds of colorectal cancer in a case-control study from Jordan. Appl. Physiol. Nutr. Metab. 2017, 42, 744-749. [CrossRef]

87. Shivappa, N.; Hebert, J.R.; Steck, S.E.; Safari, A.; Sedaghat, F.; Rashidkhani, B. Dietary Inflammatory Index and Odds of Colorectal Cancer in a Case-Control Study from Iran. Asian Pac. J. Cancer Prev. 2018, 19, 1999-2006.

88. Wirth, M.D.; Shivappa, N.; Steck, S.E.; Hurley, T.G.; Hebert, J.R. The Dietary Inflammatory Index is Associated with Colorectal Cancer in the National Institutes of Health-American Association of Retired Persons Diet and Health Study. Br. J. Nutr. 2015, 113, 1819-1827. [CrossRef]

89. Zamora-Ros, R.; Shivappa, N.; Steck, S.E.; Canzian, F.; Landi, S.; Alonso, M.H.; Hébert, J.R.; Moreno, V. Dietary inflammatory index and inflammatory gene interactions in relation to colorectal cancer risk in the Bellvitge colorectal cancer case-control study. Genes Nutr. 2015, 10, 447. [CrossRef]

90. Deng, F.E.; Shivappa, N.; Tang, Y.; Mann, J.R.; Hebert, J.R. Association between diet-related inflammation, all-cause, all-cancer, and cardiovascular disease mortality, with special focus on prediabetics: Findings from NHANES III. Eur. J. Nutr. 2016, 56, 1085-1093. [CrossRef]

91. Ratjen, I.; Shivappa, N.; Schafmayer, C.; Burmeister, G.; Nothlings, U.; Hampe, J.; Hébert, J.R.; Lieb, W.; Schlesinger, S. Association between the dietary inflammatory index and all-cause mortality in colorectal cancer long-term survivors. Int. J. Cancer 2019, 144, 1292-1301. [CrossRef] 
92. Zheng, J.; Tabung, F.K.; Zhang, J.; Murphy, E.A.; Shivappa, N.; Ockene, J.K.; Caan, B.; Kroenke, C.H.; Hébert, J.R.; Steck, S.E. Post-cancer diagnosis dietary inflammatory potential is associated with survival among women diagnosed with colorectal cancer in the Women's Health Initiative. Eur. J. Nutr. 2019, 1-13. [CrossRef]

93. Haslam, A.; Robb, S.W.; Hébert, J.R.; Huang, H.; Wirth, M.D.; Shivappa, N.; Ebell, M.H. The association between Dietary Inflammatory Index scores and the prevalence of colorectal adenoma. Public Health Nutr. 2017, 20, 1609-1616. [CrossRef]

94. Sardo Molmenti, C.L.; Steck, S.E.; Thomson, C.A.; Hibler, E.A.; Yang, J.; Shivappa, N.; Greenlee, H.; Wirth, M.D.; Neugut, A.I.; Jacobs, E.T.; et al. Dietary Inflammatory Index and Risk of Colorectal Adenoma Recurrence: A Pooled Analysis. Nutr. Cancer 2017, 69, 238-247. [CrossRef]

95. Bruner, S.D.; Jobin, C. Intestinal microbiota in inflammatory bowel disease and carcinogenesis: Implication for therapeutics. Clin. Pharmacol. Ther. 2016, 99, 585-587. [CrossRef]

96. Murphy, E.A.; Velázquez, K.T.; Herbert, K.M. Influence of High-Fat-Diet on Gut Microbiota: A Driving Force for Chronic Disease Risk. Curr. Opin. Clin. Nutr. Metab. Care 2015, 18, 515-520. [CrossRef]

97. Smith-Brown, P.; Morrison, M.; Krause, L.; Davies, P.S.W. Dairy and plant based food intakes are associated with altered faecal microbiota in 2 to 3 year old Australian children. Sci. Rep. 2016, 6, 32385. [CrossRef]

98. Wogan, G.N.; Hecht, S.S.; Felton, J.S.; Conney, A.H.; Loeb, L.A. Environmental and chemical carcinogenesis. Semin. Cancer Boil. 2004, 14, 473-486. [CrossRef]

99. Lugade, A.A.; Bogner, P.N.; Thatcher, T.H.; Sime, P.J.; Phipps, R.P.; Thanavala, Y. Cigarette Smoke Exposure Exacerbates Lung Inflammation and Compromises Immunity to Bacterial Infection. J. Immunol. 2014, 192, 5226-5235. [CrossRef]

100. Shivappa, N.; Hebert, J.; Rosato, V.; Serraino, D.; La Vecchia, C. Inflammatory potential of diet and risk of laryngeal cancer in a case-control study from Italy. Eur. J. Cancer 2016, 61, S153. [CrossRef]

101. Mazul, A.L.; Shivappa, N.; Hébert, J.R.; Steck, S.E.; Rodriguez-Ormaza, N.; Weissler, M.; Olshan, A.F.; Zevallos, J.P. Proinflammatory diet is associated with increased risk of squamous cell head and neck cancer. Int. J. Cancer 2018, 143, 1604-1610. [CrossRef]

102. Shivappa, N.; Hébert, J.R.; Zucchetto, A.; Montella, M.; Libra, M.; Garavello, W.; Rossi, M.; La Vecchia, C.; Serraino, D. Increased risk of nasopharyngeal carcinoma with increasing levels of diet-associated inflammation in an Italian case-control study. Nutr. Cancer 2016, 68, 1123-1130. [CrossRef]

103. Abe, M.; Shivappa, N.; Ito, H.; Oze, I.; Abe, T.; Shimizu, Y.; Hasegawa, Y.; Kiyohara, C.; Nomura, M.; Ogawa, Y.; et al. Dietary inflammatory index and risk of upper aerodigestive tract cancer in Japanese adults. Oncotarget 2018, 9, 24028-24040. [CrossRef]

104. Shivappa, N.; Hébert, J.R.; Rosato, V.; Garavello, W.; Serraino, D.; La Vecchia, C. Inflammatory potential of diet and risk of oral and pharyngeal cancer in a large case-control study from Italy. Int. J. Cancer 2017, 141, 471-479. [CrossRef]

105. Azzi, C.; Zhang, J.; Purdon, C.H.; Chapman, J.M.; Nitcheva, D.; Hebert, J.R.; Smith, E.W. Permeation and reservoir formation of 4-(methylnitrosamino)-1-(3-pyridyl)-1-butanone (NNK) and benzo[a]pyrene (BAP) across porcine esophageal tissue in the presence of ethanol and menthol. Carcinogenesis 2006, 27, 137-145. [CrossRef]

106. Squier, C.A.; Mantz, M.J.; Wertz, P.W. Effect of menthol on the penetration of tobacco carcinogens and nicotine across porcine oral mucosa ex vivo. Nicotine Tob. Res. 2010, 12, 763-767. [CrossRef]

107. Shivappa, N.; Hebert, J.R.; Rashidkhani, B. Dietary Inflammatory Index and risk of esophageal squamous cell cancer in a case-control study from Iran. Nutr. Cancer 2015, 67, 1253-1259. [CrossRef]

108. Shivappa, N.; Zucchetto, A.; Serraino, D.; Rossi, M.; La Vecchia, C.; Hebert, J.R. Dietary inflammatory index and risk of esophageal squamous cell cancer in a case-control study from Italy. Cancer Causes Control 2015, 26, 1439-1447. [CrossRef]

109. Lu, Y.; Shivappa, N.; Lin, Y.; Lagergren, J.; Hebert, J.R. Diet-related inflammation and oesophageal cancer by histological type: A nationwide case-control study in Sweden. Eur. J. Nutr. 2016, 55, 1683-1694. [CrossRef]

110. Shivappa, N.; Hebert, J.R.; Anderson, L.A.; Shrubsole, M.J.; Murray, L.J.; Getty, L.B.; Coleman, H.G. Dietary inflammatory index and risk of reflux oesophagitis, Barrett's oesophagus and oesophageal adenocarcinoma: A population-based case-control study. Br. J. Nutr. 2017, 117, 1323-1331. [CrossRef] 
111. Tang, L.; Shivappa, N.; Hebert, J.R.; Lee, A.H.; Xu, F.; Binns, C.W. Dietary inflammatory index and risk of oesophageal cancer in Xinjiang Uyghur Autonomous Region, China. Br. J. Nutr. 2018, 119, 1068-1075. [CrossRef]

112. Hodge, A.M.; Bassett, J.K.; Shivappa, N.; Hébert, J.R.; English, D.R.; Giles, G.G.; Severi, G. Dietary inflammatory index, Mediterranean diet score, and lung cancer: A prospective study. Cancer Causes Control 2016, 27, 907-917. [CrossRef]

113. Shivappa, N.; Wang, R.; Hébert, J.R.; Jin, A.; Koh, W.-P.; Yuan, J.M. Association between inflammatory potential of diet and risk of lung cancer among smokers in a prospective study in Singapore. Eur. J. Nutr. 2018, 1-12. [CrossRef]

114. Bodén, S.; Myte, R.; Wennberg, M.; Harlid, S.; Johansson, I.; Shivappa, N.; Hébert, J.R.; Van Guelpen, B.; Nilsson, L.M. The inflammatory potential of diet in determining cancer risk; A prospective investigation of two dietary pattern scores. PLOS ONE 2019, 14, e0214551. [CrossRef]

115. Maisonneuve, P.; Shivappa, N.; Hebert, J.R.; Bellomi, M.; Rampinelli, C.; Bertolotti, R.; Spaggiari, L.; Palli, D.; Veronesi, G.; Gnagnarella, P. Dietary inflammatory index and risk of lung cancer and other respiratory conditions among heavy smokers in the COSMOS screening study. Eur. J. Nutr. 2015, 55, 1069-1079. [CrossRef]

116. Shivappa, N.; Hebert, J.R.; Rosato, V.; Rossi, M.; Libra, M.; Montella, M.; Serraino, D.; La Vecchia, C. Dietary Inflammatory Index and Risk of Bladder Cancer in a Large Italian Case-Control Study. Urology 2017, 100, 84-89. [CrossRef]

117. Shivappa, N.; Hebert, J.R.; Mirsafa, F.; Rashidkhani, B. Increased Inflammatory Potential of Diet Is Associated with Increased Risk of Bladder Cancer in an Iranian Case-Control Study. Nutr. Cancer 2019, 1-8. [CrossRef]

118. Shivappa, N.; Blair, C.K.; Prizment, A.E.; Jacobs, D.R.; Hébert, J.R. Dietary inflammatory index and risk of renal cancer in the Iowa Women's Health Study. Eur. J. Nutr. 2017, 57, 1207-1213. [CrossRef]

119. Shivappa, N.; Hébert, J.R.; Rosato, V.; Rossi, M.; Montella, M.; Serraino, D.; La Vecchia, C. Dietary Inflammatory Index and Renal Cell Carcinoma Risk in an Italian Case-Control Study. Nutr. Cancer 2017, 69, 833-839. [CrossRef]

120. Shivappa, N.; Bosetti, C.; Zucchetto, A.; Serraino, D.; La Vecchia, C.; Hebert, J.R. Dietary inflammatory index and risk of pancreatic cancer in an Italian case-control study. Br. J. Nutr. 2015, 113, 292-298. [CrossRef]

121. Antwi, S.O.; Oberg, A.L.; Shivappa, N.; Bamlet, W.R.; Chaffee, K.G.; Steck, S.E.; Hebert, J.R.; Petersen, G.M. Pancreatic cancer: Associations of inflammatory potential of diet, cigarette smoking and long-standing diabetes. Carcinogenesis 2016, 37, 481-490. [CrossRef]

122. Antwi, S.O.; Bamlet, W.R.; Pedersen, K.S.; Chaffee, K.G.; Risch, H.A.; Shivappa, N.; Steck, S.E.; Anderson, K.E.; Bracci, P.M.; Polesel, J.; et al. Pancreatic Cancer Risk is Modulated by Inflammatory Potential of Diet and ABO Genotype: A Consortia-based Evaluation and Replication Study. Carcinogenesis 2018. [CrossRef]

123. Zheng, J.; Merchant, A.T.; Wirth, M.D.; Zhang, J.; Antwi, S.O.; Shoaibi, A.; Shivappa, N.; Stolzenberg-Solomon, R.Z.; Hebert, J.R.; Steck, S.E. Inflammatory potential of diet and risk of pancreatic cancer in the Prostate, Lung, Colorectal and Ovarian (PLCO) Cancer Screening Trial. Int. J. Cancer 2018, 142, 2461-2470. [CrossRef]

124. Zheng, J.; Wirth, M.D.; Merchant, A.T.; Zhang, J.; Shivappa, N.; Stolzenberg-Solomon, R.Z.; Hebert, J.R.; Steck, S.E. Inflammatory potential of diet, inflammation-related lifestyle factors and risk of pancreatic cancer: Results from the NIH-AARP Diet and Health Study. Cancer Epidemiol. Biomark. Prev. 2019. [CrossRef]

125. Shivappa, N.; Hebert, J.R.; Polesel, J.; Zucchetto, A.; Crispo, A.; Montella, M.; Franceschi, S.; Rossi, M.; La Vecchia, C.; Serraino, D. Inflammatory potential of diet and risk for hepatocellular cancer in a case-control study from Italy. Br. J. Nutr. 2016, 115, 324-331. [CrossRef]

126. Wang, X.-Y.; Fang, A.-P.; Chen, P.-Y.; Liao, G.-C.; Zhang, Y.-J.; Shivappa, N.; Hébert, J.R.; Chen, Y.-M.; Zhu, H.-L. High dietary inflammatory index scores are associated with an elevated risk of hepatocellular carcinoma in a case-control study. Food Funct. 2018, 9, 5832-5842. [CrossRef]

127. Shivappa, N.; Hébert, J.R.; Ferraroni, M.; La Vecchia, C.; Rossi, M. Association between dietary inflammatory index and gastric cancer risk in an Italian case-control study. Nutr. Cancer 2016, 68, 1262-1268. [CrossRef]

128. Graffouillère, L.; Deschasaux, M.; Mariotti, F.; Neufcourt, L.; Shivappa, N.; Hébert, J.R.; Wirth, M.D.; Latino-Martel, P.; Hercberg, S.; Galan, P.; et al. The Dietary Inflammatory Index Is Associated with Prostate Cancer Risk in French Middle-Aged Adults in a Prospective Study. J. Nutr. 2016, 146, 785-791. [CrossRef] 
129. Hoang, D.V.; Shivappa, N.; Pham, N.M.; Hebert, J.R.; Binns, C.W.; Lee, A.H. Dietary inflammatory index is associated with increased risk for prostate cancer among Vietnamese men. Nutrition 2019, 62, 140-145. [CrossRef]

130. McMahon, D.M.; Burch, J.B.; Hebert, J.R.; Hardin, J.W.; Zhang, J.; Wirth, M.D.; Youngstedt, S.D.; Shivappa, N.; Jacobsen, S.J.; Caan, B.; et al. Diet-related inflammation and risk of prostate cancer in the California Men's Health Study. Ann. Epidemiol. 2018. [CrossRef]

131. Shivappa, N.; Bosetti, C.; Zucchetto, A.; Montella, M.; Serraino, D.; La Vecchia, C.; Hebert, J.R. Association between dietary inflammatory index and prostate cancer among Italian men. Br. J. Nutr. 2014, 113, 278-283. [CrossRef]

132. Shivappa, N.; Jackson, M.D.; Bennett, F.; Hebert, J.R. Increased Dietary Inflammatory Index (DII) Is Associated With Increased Risk of Prostate Cancer in Jamaican Men. Nutr. Cancer 2015, 67, 941-948. [CrossRef]

133. Shivappa, N.; Hebert, J.R.; Askari, F.; Kardoust Parizi, M.; Rashidkhani, B. Increased Inflammatory Potential of Diet is Associated with Increased Risk of Prostate Cancer in Iranian Men. Int. J. Vitam. Nutr. Res. Int. Z. Vitam. 2017, 86, 161-168. [CrossRef]

134. Shivappa, N.; Miao, Q.; Walker, M.; Hébert, J.R.; Aronson, K.J. Association Between a Dietary Inflammatory Index and Prostate Cancer Risk in Ontario, Canada. Nutr. Cancer 2017, 69, 825-832. [CrossRef]

135. Shivappa, N.; Niclis, C.; Coquet, J.B.; Román, M.D.; Hébert, J.R.; Diaz, M.D.P. Increased inflammatory potential of diet is associated with increased odds of prostate cancer in Argentinian men. Cancer Causes Control 2018, 29, 803-813. [CrossRef]

136. Vázquez-Salas, R.A.; Shivappa, N.; Galván-Portillo, M.; López-Carrillo, L.; Hébert, J.R.; Torres-Sánchez, L. Dietary inflammatory index and prostate cancer risk in a case-control study in Mexico. Br. J. Nutr. 2016, 116, 1945-1953. [CrossRef]

137. Vidal, A.C.; Oyekunle, T.; Howard, L.E.; Shivappa, N.; De Hoedt, A.; Figueiredo, J.C.; Taioli, E.; Fowke, J.H.; Lin, P.H.; Hebert, J.R.; et al. Dietary inflammatory index (DII) and risk of prostate cancer in a case-control study among Black and White US Veteran men. Prostate Cancer Prostatic Dis. 2019. [CrossRef]

138. Zucchetto, A.; Gini, A.; Shivappa, N.; Hebert, J.R.; Stocco, C.; Maso, L.D.; Birri, S.; Serraino, D.; Polesel, J. Dietary inflammatory index and prostate cancer survival. Int. J. Cancer 2016, 139, 2398-2404. [CrossRef]

139. Shivappa, N.; Sandin, S.; Löf, M.; Hébert, J.R.; Adami, H.-O.; Weiderpass, E. Prospective study of dietary inflammatory index and risk of breast cancer in Swedish women. Br. J. Cancer 2015, 113, 1099-1103. [CrossRef]

140. Huang, W.-Q.; Mo, X.-F.; Ye, Y.-B.; Shivappa, N.; Lin, F.-Y.; Huang, J.; Hébert, J.R.; Yan, B.; Zhang, C.-X. A higher Dietary Inflammatory Index score is associated with a higher risk of breast cancer among Chinese women: A case-control study. Br. J. Nutr. 2017, 117, 1358-1367. [CrossRef]

141. Shivappa, N.; Blair, C.K.; Prizment, A.E.; Jacobs, D.R.; Hébert, J.R. Prospective study of the dietary inflammatory index and risk of breast cancer in postmenopausal women. Mol. Nutr. Food Res. 2017, 61, 87. [CrossRef]

142. Shivappa, N.; Hebert, J.R.; Rosato, V.; Montella, M.; Serraino, D.; La Vecchia, C. Association between the dietary inflammatory index and breast cancer in a large Italian case-control study. Mol. Nutr. Food Res. 2017, 61. [CrossRef]

143. Jalali, S.; Shivappa, N.; Hébert, J.R.; Heidari, Z.; Hekmatdoost, A.; Rashidkhani, B. Dietary Inflammatory Index and Odds of Breast Cancer in a Case-Control Study from Iran. Nutr. Cancer 2018, 70, 1034-1042. [CrossRef]

144. Gardeazabal, I.; Ruiz-Canela, M.; Sánchez-Bayona, R.; Romanos-Nanclares, A.; Aramendía-Beitia, J.; Shivappa, N.; Hébert, J.; Martínez-González, M.; Toledo, E. Dietary inflammatory index and incidence of breast cancer in the SUN project. Clin. Nutr. 2018. [CrossRef]

145. Ge, I.; Rudolph, A.; Shivappa, N.; Flesch-Janys, D.; Hebert, J.R.; Chang-Claude, J. Dietary inflammation potential and postmenopausal breast cancer risk in a German case-control study. Breast 2015, 24, 491-496. [CrossRef]

146. Zheng, J.; Tabung, F.K.; Zhang, J.; Liese, A.D.; Shivappa, N.; Ockene, J.K.; Caan, B.; Kroenke, C.H.; Hebert, J.R.; Steck, S.E. Association between Post-Cancer Diagnosis Dietary Inflammatory Potential and Mortality among Invasive Breast Cancer Survivors in the Women's Health Initiative. Cancer Epidemiol. Biomark. Prev. 2018, 27, 454-463. [CrossRef] 
147. Tabung, F.K.; Steck, S.E.; Liese, A.D.; Zhang, J.; Ma, Y.; Caan, B.; Chlebowski, R.T.; Freudenheim, J.L.; Hou, L.; Mossavar-Rahmani, Y.; et al. Association between dietary inflammatory potential and breast cancer incidence and death: Results from the Women's Health Initiative. Br. J. Cancer 2016, 114, 1277-1285. [CrossRef]

148. Zucchetto, A.; Serraino, D.; Shivappa, N.; Hébert, J.R.; Stocco, C.; Puppo, A.; Falcini, F.; Panato, C.; Maso, L.D.; Polesel, J. Dietary inflammatory index before diagnosis and survival in an Italian cohort of women with breast cancer. Br. J. Nutr. 2017, 117, 1456-1462. [CrossRef]

149. Shivappa, N.; Hebert, J.R.; Rosato, V.; Rossi, M.; Montella, M.; Serraino, D.; La Vecchia, C. Dietary Inflammatory Index and ovarian cancer risk in a large Italian case-control study. Cancer Causes Control 2016, 27, 897-906. [CrossRef]

150. Nagle, C.M.; Ibiebele, T.; Shivappa, N.; Hébert, J.R.; DeFazio, A.; Webb, P.M.; Australian Ovarian Cancer Study. The association between the inflammatory potential of diet and risk of developing, and survival following, a diagnosis of ovarian cancer. Eur. J. Nutr. 2018, 58, 1747-1756. [CrossRef]

151. Shivappa, N.; Hebert, J.R.; Paddock, L.E.; Rodriguez-Rodriguez, L.; Olson, S.H.; Bandera, E.V. Dietary inflammatory index and ovarian cancer risk in a New Jersey case-control study. Nutrition 2018, 46, 78-82. [CrossRef]

152. Peres, L.C.; Bandera, E.V.; Qin, B.; Guertin, K.A.; Shivappa, N.; Hebert, J.R.; Abbott, S.E.; Alberg, A.J.; Barnholtz-Sloan, J.; Bondy, M.; et al. Dietary inflammatory index and risk of epithelial ovarian cancer in African American women. Int. J. Cancer 2017, 140, 535-543. [CrossRef]

153. Shivappa, N.; Hebert, J.R.; Zucchetto, A.; Montella, M.; Serraino, D.; La Vecchia, C.; Rossi, M. Dietary inflammatory index and endometrial cancer risk in an Italian case-control study. Br. J. Nutr. 2016, 115, 138-146. [CrossRef]

154. Shivappa, N.; Hébert, J.R.; Taborelli, M.; Montella, M.; Libra, M.; Zucchetto, A.; Crispo, A.; Grimaldi, M.; La Vecchia, C.; Serraino, D.; et al. Dietary Inflammatory Index and Non-Hodgkin Lymphoma risk in an Italian case-control study. Cancer Causes Control 2017, 28, 791-799. [CrossRef]

155. Shivappa, N.; Hebert, J.R.; Taborelli, M.; Zucchetto, A.; Montella, M.; Libra, M.; La Vecchia, C.; Serraino, D.; Polesel, J. Association between dietary inflammatory index and Hodgkin's lymphoma in an Italian case-control study. Nutrition 2018, 53, 43-48. [CrossRef]

156. Guo, F.; Moellering, D.R.; Garvey, W.T. The progression of cardiometabolic disease: Validation of a new cardiometabolic disease staging system applicable to obesity. Obesity 2014, 22, 110-118. [CrossRef]

157. Vincent, G.E.; Jay, S.M.; Sargent, C.; Vandelanotte, C.; Ridgers, N.D.; Ferguson, S.A. Improving Cardiometabolic Health with Diet, Physical Activity, and Breaking Up Sitting: What about Sleep? Front. Physiol. 2017, 8, 856. [CrossRef]

158. Phillips, C.M.; Perry, I.J. Does Inflammation Determine Metabolic Health Status in Obese and Nonobese Adults? J. Clin. Endocrinol. Metab. 2013, 98, E1610-E1619. [CrossRef]

159. Choi, J.; Se-Young, O.; Lee, D.; Tak, S.; Hong, M.; Park, S.M.; Cho, B.; Park, M. Characteristics of diet patterns in metabolically obese, normal weight adults (Korean National Health and Nutrition Examination Survey III, 2005). Nutr. Metab. Cardiovasc. Dis. 2012, 22, 567-574. [CrossRef]

160. Misra, A.; Bhardwaj, S. Obesity and the metabolic syndrome in developing countries: Focus on South Asians. Nestle Nutr. Inst. Workshop Ser. 2014, 78, 133-140.

161. Kelishadi, R.; Hashemipour, M.; Sarrafzadegan, N.; Mohammadifard, N.; Alikhasy, H.; Beizaei, M.; Sajjadi, F.; Poursafa, P.; Amin, Z.; Ghatreh-Samani, S.; et al. Effects of a lifestyle modification trial among phenotypically obese metabolically normal and phenotypically obese metabolically abnormal adolescents in comparison with phenotypically normal metabolically obese adolescents. Matern. Child Nutr. 2010, 6, 275-286. [CrossRef]

162. Hebert, J.R.; Wirth, M.; Davis, L.; Davis, B.; Harmon, B.E.; Hurley, T.G.; Drayton, R.; Angela Murphy, E.; Shivappa, N.; Wilcox, S.; et al. C-reactive protein levels in African Americans: A diet and lifestyle randomized community trial. Am. J. Prev. Med. 2013, 45, 430-440. [CrossRef]

163. WHO (World Health Organization). Global Health Estimates 2016: Disease Burden by Cause, Age, Sex, by Country and by Region, 2000-2016; World Health Organization: Geneva, Switherland, 2018.

164. Emerging Risk Factors, C.; Kaptoge, S.; Di Angelantonio, E.; Lowe, G.; Pepys, M.B.; Thompson, S.G.; Collins, R.; Danesh, J. C-reactive protein concentration and risk of coronary heart disease, stroke, and mortality: An individual participant meta-analysis. Lancet 2010, 375, 132-140.

165. Ridker, P.M.; Tracy, R.P.; Hennekens, C.H.; Cushman, M.; Stampfer, M.J. Inflammation, Aspirin, and the Risk of Cardiovascular Disease in Apparently Healthy Men. N. Engl. J. Med. 1997, 336, 973-979. [CrossRef] 
166. Spranger, J.; Kroke, A.; Möhlig, M.; Hoffmann, K.; Bergmann, M.M.; Ristow, M.; Boeing, H.; Pfeiffer, A.F.H. Inflammatory Cytokines and the Risk to Develop Type 2 Diabetes: Results of the Prospective Population-Based European Prospective Investigation into Cancer and Nutrition (EPIC)-Potsdam Study. Diabetes 2003, 52, 812-817. [CrossRef]

167. Pradhan, A.D.; Manson, J.E.; Rifai, N.; Buring, J.E.; Ridker, P.M. C-Reactive Protein, Interleukin 6, and Risk of Developing Type 2 Diabetes Mellitus. JAMA 2001, 286, 327-334. [CrossRef]

168. Festa, A.; D'Agostino, R.; Tracy, R.P.; Haffner, S.M. Elevated Levels of Acute-Phase Proteins and Plasminogen Activator Inhibitor-1 Predict the Development of Type 2 Diabetes: The Insulin Resistance Atherosclerosis Study. Diabetes 2002, 51, 1131-1137. [CrossRef]

169. Kord Varkaneh, H.; Fatahi, S.; Tajik, S.; Rahmani, J.; Zarezadeh, M.; Shab-Bidar, S. Dietary inflammatory index in relation to obesity and body mass index: A meta-analysis. Nutr. Food Sci. 2018, 48, 702-721. [CrossRef]

170. Namazi, N.; Larijani, B.; Azadbakht, L. Dietary Inflammatory Index and its Association with the Risk of Cardiovascular Diseases, Metabolic Syndrome, and Mortality: A Systematic Review and Meta-Analysis. Horm. Metab. Res. 2018, 50, 345-358. [CrossRef]

171. Ruiz-Canela, M.; Bes-Rastrollo, M.; Martinez-Gonzalez, M.A. The Role of Dietary Inflammatory Index in Cardiovascular Disease, Metabolic Syndrome and Mortality. Int. J. Mol. Sci. 2016, 17, 1265. [CrossRef]

172. Jorgensen, D.; White, G.E.; Sekikawa, A.; Gianaros, P. Higher dietary inflammation is associated with increased odds of depression independent of Framingham Risk Score in the National Health and Nutrition Examination Survey. Nutr. Res. 2018, 54, 23-32. [CrossRef]

173. Okada, E.; Shirakawa, T.; Shivappa, N.; Wakai, K.; Suzuki, K.; Date, C.; Iso, H.; Hébert, J.R.; Tamakoshi, A. Dietary Inflammatory Index Is Associated with Risk of All-Cause and Cardiovascular Disease Mortality but Not with Cancer Mortality in Middle-Aged and Older Japanese Adults. J. Nutr. 2019, 149, 1451-1459. [CrossRef]

174. Ramallal, R.; Toledo, E.; Martinez-Gonzalez, M.A.; Hernández-Hernández, A.; García-Arellano, A.; Shivappa, N.; Hebert, J.R.; Ruíz-Canela, M. Dietary Inflammatory Index and Incidence of Cardiovascular Disease in the SUN Cohort. PLoS ONE 2015, 10, e0135221. [CrossRef]

175. Shivappa, N.; Steck, S.E.; Hussey, J.R.; Ma, Y.; Hebert, J.R. Inflammatory potential of diet and all-cause, cardiovascular, and cancer mortality in National Health and Nutrition Examination Survey III Study. Eur. J. Nutr. 2017, 56, 683-692. [CrossRef]

176. Willerson, J.T.; Ridker, P.M. Inflammation as a Cardiovascular Risk Factor. Circulation 2004, 109, II-2-II-10. [CrossRef]

177. Sokol, A.; Wirth, M.D.; Manczuk, M.; Shivappa, N.; Zatonska, K.; Hurley, T.G.; Hébert, J.R. Association between the dietary inflammatory index, waist-to-hip ratio and metabolic syndrome. Nutr. Res. 2016, 36, 1298-1303. [CrossRef]

178. Carvalho, C.A.; Silva, A.A.M.; Assunção, M.C.F.; Fonseca, P.C.A.; Barbieri, M.A.; Bettiol, H.; Shivappa, N.; Hébert, J.R. The dietary inflammatory index and insulin resistance or metabolic syndrome in young adults. Nutrition 2019, 58, 187-193. [CrossRef]

179. Kim, H.-Y.; Lee, J.; Kim, J. Association between Dietary Inflammatory Index and Metabolic Syndrome in the General Korean Population. Nutrients 2018, 10, 648. [CrossRef]

180. Ren, Z.; Zhao, A.; Wang, Y.; Meng, L.; Szeto, I.M.-Y.; Li, T.; Gong, H.; Tian, Z.; Zhang, Y.; Wang, P. Association between Dietary Inflammatory Index, C-Reactive Protein and Metabolic Syndrome: A Cross-Sectional Study. Nutrients 2018, 10, 831. [CrossRef]

181. Welsh, P.; Polisecki, E.; Robertson, M.; Jahn, S.; Buckley, B.M.; de Craen, A.J.; Ford, I.; Jukema, J.W.; Macfarlane, P.W.; Packard, C.J.; et al. Unraveling the directional link between adiposity and inflammation: A bidirectional Mendelian randomization approach. J. Clin. Endocrinol. Metab. 2010, 95, 93-99. [CrossRef]

182. Van Zuydam, N.; Wielscher, M.; McCarthy, M.; Järvelin, M.-R. Increased Obesity Is Causal for Increased Inflammation-A Mendelian Randomisation Study. Diabetes 2018, 67, 217. [CrossRef]

183. Alam, I.; Shivappa, N.; Hebert, J.R.; Pawelec, G.; Larbi, A. Relationships between the inflammatory potential of the diet, aging and anthropometric measurements in a cross-sectional study in Pakistan. Nutr. Health Aging 2018, 4, 335-343. [CrossRef]

184. Aslani, Z.; Qorbani, M.; Hebert, J.R.; Shivappa, N.; Motlagh, M.E.; Asayesh, H.; Mahdavi-Gorabi, A.; Kelishadi, R. Association of Dietary Inflammatory Index with anthropometric indices in children and adolescents: The weight disorder survey of the Childhood and Adolescence Surveillance and Prevention of Adult Non-communicable Disease (CASPIAN)-IV study. Br. J. Nutr. 2019, 121, 340-350. [CrossRef] 
185. Andrade, P.A.; Hermsdorff, H.H.M.; Leite, J.I.A.; Shivappa, N.; Hebert, J.R.; Henriques, H.K.F.; de Oliveira Barbosa Rosa, C. Baseline Pro-inflammatory Diet Is Inversely Associated with Change in Weight and Body Fat 6 Months Following-up to Bariatric Surgery. Obes. Surg. 2019, 29, 457-463. [CrossRef]

186. Denova-Gutiérrez, E.; Muñoz-Aguirre, P.; Shivappa, N.; Hébert, J.R.; Tolentino-Mayo, L.; Batis, C.; Barquera, S. Dietary Inflammatory Index and Type 2 Diabetes Mellitus in Adults: The Diabetes Mellitus Survey of Mexico City. Nutrients 2018, 10, 385. [CrossRef]

187. Shivappa, N.; Hébert, J.R.; Akhoundan, M.; Mirmiran, P.; Rashidkhani, B. Association between inflammatory potential of diet and odds of gestational diabetes mellitus among Iranian women. J. Matern. Fetal Neonatal Med. 2018, 32, 3552-3558. [CrossRef]

188. Vahid, F.; Shivappa, N.; Karamati, M.; Jafari Naeini, A.; Hebert, J.R.; Davoodi, S.H. Association between Dietary Inflammatory Index (DII) and Risk of Pre-Diabetes: A Case-Control Study. Appl. Physiol. Nutr. Metab. 2016, 42, 399-404. [CrossRef]

189. Beckhaus, A.A.; Garcia-Marcos, L.; Forno, E.; Pacheco-Gonzalez, R.M.; Celedón, J.C.; Castro-Rodriguez, J.A.; Garcia-Marcos, L.; Pacheco-Gonzalez, R.M.; Castro-Rodriguez, J.A. Maternal nutrition during pregnancy and risk of asthma, wheeze and atopic diseases during childhood: A systematic review and meta-analysis. Allergy 2015, 70, 1588-1604. [CrossRef]

190. Guilleminault, L.; Williams, E.J.; Scott, H.A.; Berthon, B.S.; Jensen, M.; Wood, L.G. Diet and Asthma: Is It Time to Adapt Our Message? Nutrients 2017, 9, 1227. [CrossRef]

191. Berthon, B.S.; MacDonald-Wicks, L.K.; Gibson, P.G.; Wood, L.G. Investigation of the association between dietary intake, disease severity and airway inflammation in asthma. Respirology 2013, 18, 447-454. [CrossRef]

192. Wood, L.G.; Gibson, P.G. Dietary factors lead to innate immune activation in asthma. Pharmacol. Ther. 2009, 123, 37-53. [CrossRef]

193. Devereux, G. The increase in the prevalence of asthma and allergy: Food for thought. Nat. Rev. Immunol. 2006, 6, 869-874. [CrossRef]

194. Hosseini, B.; Berthon, B.S.; Wark, P.; Wood, L.G. Effects of Fruit and Vegetable Consumption on Risk of Asthma, Wheezing and Immune Responses: A Systematic Review and Meta-Analysis. Nutrients 2017, 9, 341. [CrossRef]

195. Wood, L.G.; Shivappa, N.; Berthon, B.S.; Gibson, P.G.; Hebert, J.R. Dietary inflammatory index is related to asthma risk, lung function and systemic inflammation in asthma. Clin. Exp. Allergy 2015, 45, 177-183. [CrossRef]

196. Han, Y.-Y.; Forno, E.; Shivappa, N.; Wirth, M.D.; Hébert, J.R.; Celedón, J.C. The Dietary Inflammatory Index and Current Wheeze Among Children and Adults in the United States. J. Allergy Clin. Immunol. Pract. 2018, 6, 834-841. [CrossRef]

197. Duijts, L.; Reiss, I.K.; Brusselle, G.; De Jongste, J.C. Early origins of chronic obstructive lung diseases across the life course. Eur. J. Epidemiol. 2014, 29, 871-885. [CrossRef]

198. Shaheen, S.O.; Northstone, K.; Newson, R.B.; Emmett, P.; Sherriff, A.; Henderson, A.J. Dietary patterns in pregnancy and respiratory and atopic outcomes in childhood. Thorax 2009, 64, 411-417. [CrossRef]

199. Lange, N.E.; Rifas-Shiman, S.L.; Camargo, C.A.; Gold, D.R.; Gillman, M.W.; Litonjua, A.A. Maternal dietary pattern during pregnancy is not associated with recurrent wheeze in children. J. Allergy Clin. Immunol. 2010, 126, 250-255. [CrossRef]

200. Miyake, Y.; Sasaki, S.; Tanaka, K.; Ohfuji, S.; Hirota, Y. Maternal fat consumption during pregnancy and risk of wheeze and eczema in Japanese infants aged 16-24 months: The Osaka Maternal and Child Health Study. Thorax 2009, 64, 815-821. [CrossRef]

201. Miyake, Y.; Okubo, H.; Sasaki, S.; Tanaka, K.; Hirota, Y. Maternal dietary patterns during pregnancy and risk of wheeze and eczema in Japanese infants aged 16-24 months: The Osaka Maternal and Child Health Study. Pediatr. Allergy Immunol. 2011, 22, 734-741. [CrossRef]

202. Willers, S.M.; Devereux, G.; Craig, L.C.A.; McNeill, G.; Wijga, A.H.; El-Magd, W.A.; Turner, S.W.; Helms, P.J.; Seaton, A. Maternal food consumption during pregnancy and asthma, respiratory and atopic symptoms in 5-year-old children. Thorax 2007, 62, 773-779. [CrossRef]

203. Miyake, Y.; Sasaki, S.; Tanaka, K.; Hirota, Y. Consumption of vegetables, fruit, and antioxidants during pregnancy and wheeze and eczema in infants. Allergy 2010, 65, 758-765. [CrossRef] 
204. Thorsen, J.; Bisgaard, H.; Chawes, B.L.; Vissing, N.H.; Schoos, A.-M.M.; Wolsk, H.M.; Pedersen, T.M.; Vinding, R.K.; Følsgaard, N.V.; Fink, N.R.; et al. Fish Oil-Derived Fatty Acids in Pregnancy and Wheeze and Asthma in Offspring. N. Engl. J. Med. 2016, 375, 2530-2539.

205. Sen, S.; Rifas-Shiman, S.L.; Shivappa, N.; Wirth, M.D.; Hébert, J.R.; Gold, D.R.; Gillman, M.W.; Oken, E. Dietary Inflammatory Potential during Pregnancy Is Associated with Lower Fetal Growth and Breastfeeding Failure: Results from Project Viva. J. Nutrients 2016, 146, 728-736. [CrossRef]

206. Sonnenschein-van der Voort, A.M.; Jaddoe, V.W.; Moll, H.A.; Hofman, A.; van der Valk, R.J.; de Jongste, J.C.; Duijts, L. Influence of maternal and cord blood C-reactive protein on childhood respiratory symptoms and eczema. Pediatr. Allergy Immunol. 2013, 24, 469-475. [CrossRef]

207. Prado, E.L.; Dewey, K.G. Nutrition and brain development in early life. Nutr. Rev. 2014, 72, $267-284$. [CrossRef]

208. Borge, T.C.; Aase, H.; Brantsæter, A.L.; Biele, G. The importance of maternal diet quality during pregnancy on cognitive and behavioural outcomes in children: A systematic review and meta-analysis. BMJ Open 2017, 7, e016777. [CrossRef]

209. González, H.F.; Visentin, S. Micronutrients and neurodevelopment: An update. Arch. Argent. Pediatr. 2016, 114, 570-575.

210. Iglesias, L.; Canals, J.; Arija, V. Effects of prenatal iron status on child neurodevelopment and behavior: A systematic review. Crit. Rev. Food Sci. Nutr. 2018, 58, 1604-1614. [CrossRef]

211. Amorós, R.; Murcia, M.; González, L.; Rebagliato, M.; Iniguez, C.; Lopez-Espinosa, M.-J.; Vioque, J.; Broberg, K.; Ballester, F.; Llop, S. Maternal selenium status and neuropsychological development in Spanish preschool children. Environ. Res. 2018, 166, 215-222. [CrossRef]

212. Barker, E.D.; Kirkham, N.; Ng, J.; Jensen, S.K.G. Prenatal maternal depression symptoms and nutrition, and child cognitive function. Br. J. Psychiatry 2013, 203, 417-421. [CrossRef]

213. Daniels, J.L.; Longnecker, M.P.; Rowland, A.S.; Golding, J. Fish Intake During Pregnancy and Early Cognitive Development of Offspring. Epidemiology 2004, 15, 394-402. [CrossRef]

214. Davidson, P.W.; Strain, J.; Myers, G.J.; Thurston, S.W.; Bonham, M.P.; Shamlaye, C.F.; Stokes-Riner, A.; Wallace, J.M.; Robson, P.J.; Duffy, E.M.; et al. Neurodevelopmental Effects of Maternal Nutritional Status and Exposure to Methylmercury from Eating Fish during Pregnancy. NeuroToxicology 2008, 29, 767-775. [CrossRef]

215. Gale, C.R.; Robinson, S.M.; Godfrey, K.M.; Law, C.M.; Schlotz, W.; O'Callaghan, F.J. Oily fish intake during pregnancy-Association with lower hyperactivity but not with higher full-scale IQ in offspring. J. Child Psychol. Psychiatry 2008, 49, 1061-1068. [CrossRef]

216. Hibbeln, J.R.; Davis, J.M.; Steer, C.; Emmett, P.; Rogers, I.; Williams, C.; Golding, J. Maternal seafood consumption in pregnancy and neurodevelopmental outcomes in childhood (ALSPAC study): An observational cohort study. Lancet 2007, 369, 578-585. [CrossRef]

217. Jacka, F.N.; Ystrom, E.; Brantsaeter, A.L.; Karevold, E.; Roth, C.; Haugen, M.; Meltzer, H.M.; Schjolberg, S.; Berk, M. Maternal and Early Postnatal Nutrition and Mental Health of Offspring by Age 5 Years: A Prospective Cohort Study. J. Am. Acad. Child Adolesc. Psychiatry 2013, 52, 1038-1047. [CrossRef]

218. Mendez, M.A.; Torrent, M.; Julvez, J.; Ribas-Fitó, N.; Kogevinas, M.; Sunyer, J. Maternal fish and other seafood intakes during pregnancy and child neurodevelopment at age 4 years. Public Health Nutr. 2009, 12, 1702-1710. [CrossRef]

219. Oken, E.; Radesky, J.S.; Wright, R.O.; Bellinger, D.C.; Amarasiriwardena, C.J.; Kleinman, K.P.; Hu, H.; Gillman, M.W. Maternal Fish Intake During Pregnancy, Blood Mercury Levels, and Child Cognition at Age 3 Years in a US Cohort. Obstet. Gynecol. Surv. 2008, 63, 557-558. [CrossRef]

220. Oken, E.; Østerdal, M.L.; Gillman, M.W.; Knudsen, V.K.; Halldorsson, T.I.; Strøm, M.; Bellinger, D.C.; Hadders-Algra, M.; Michaelsen, K.F.; Olsen, S.F. Associations of maternal fish intake during pregnancy and breastfeeding duration with attainment of developmental milestones in early childhood: A study from the Danish National Birth Cohort. Am. J. Clin. Nutr. 2008, 88, 789-796. [CrossRef]

221. Pina-Camacho, L.; Jensen, S.K.; Gaysina, D.; Barker, E.D. Maternal depression symptoms, unhealthy diet and child emotional-behavioural dysregulation. Psychol. Med. 2015, 45, 1851-1860. [CrossRef]

222. Steenweg-de Graaff, J.; Tiemeier, H.; Steegers-Theunissen, R.P.; Hofman, A.; Jaddoe, V.W.; Verhulst, F.C.; Roza, S.J. Maternal dietary patterns during pregnancy and child internalising and externalising problems. The Generation R Study. Clin. Nutr. 2014, 33, 115-121. [CrossRef] 
223. Valent, F.; Mariuz, M.; Bin, M.; Little, D.; Mazej, D.; Tognin, V.; Tratnik, J.; McAfee, A.J.; Mulhern, M.S.; Parpinel, M.; et al. Associations of Prenatal Mercury Exposure From Maternal Fish Consumption and Polyunsaturated Fatty Acids With Child Neurodevelopment: A Prospective Cohort Study in Italy. J. Epidemiol. 2013, 23, 360-370. [CrossRef]

224. Sagiv, S.K.; Thurston, S.W.; Bellinger, D.C.; Amarasiriwardena, C.; Korrick, S.A. Prenatal exposure to mercury and fish consumption during pregnancy and attention-deficit/hyperactivity disorder-related behavior in children. Arch. Pediatr. Adolesc. Med. 2012, 166, 1123-1131. [CrossRef]

225. The EDEN Mother-Child Cohort Study Group; Bernard, J.Y.; De Agostini, M.; Forhan, A.; De Lauzon-Guillain, B.; Charles, M.-A.; Heude, B. The Dietary n6, n3 Fatty Acid Ratio during Pregnancy Is Inversely Associated with Child Neurodevelopment in the EDEN Mother-Child Cohort. J. Nutr. 2013, 143, 1481-1488.

226. Bolduc, F.V.; Lau, A.; Rosenfelt, C.S.; Langer, S.; Wang, N.; Smithson, L.; Lefebvre, D.; Alexander, R.T.; Dickson, C.T.; Li, L.; et al. Cognitive Enhancement in Infants Associated with Increased Maternal Fruit Intake During Pregnancy: Results from a Birth Cohort Study with Validation in an Animal Model. EBioMedicine 2016, 8, 331-340. [CrossRef]

227. Gustafsson, H.C.; Kuzava, S.E.; Werner, E.A.; Monk, C. Maternal dietary fat intake during pregnancy is associated with infant temperament. Dev. Psychobiol. 2016, 58, 528-535. [CrossRef]

228. Julvez, J.; Mendez, M.; Fernández-Barrés, S.; Romaguera, D.; Vioque, J.; Llop, S.; Ibarluzea, J.; Guxens, M.; Avella-Garcia, C.; Tardón, A.; et al. Maternal Consumption of Seafood in Pregnancy and Child Neuropsychological Development: A Longitudinal Study Based on a Population With High Consumption Levels. Am. J. Epidemiol. 2016, 183, 169-182. [CrossRef]

229. Oken, E.; Rifas-Shiman, S.L.; Amarasiriwardena, C.; Jayawardene, I.; Bellinger, D.C.; Hibbeln, J.R.; Wright, R.O.; Gillman, M.W. Maternal prenatal fish consumption and cognition in mid childhood: Mercury, fatty acids, and selenium. Neurotoxicol. Teratol. 2016, 57, 71-78. [CrossRef]

230. Malin, A.J.; Busgang, S.A.; Cantoral, A.J.; Svensson, K.; Orjuela, M.A.; Pantic, I.; Schnaas, L.; Oken, E.; Baccarelli, A.A.; Téllez-Rojo, M.M.; et al. Quality of Prenatal and Childhood Diet Predicts Neurodevelopmental Outcomes among Children in Mexico City. Nutrients 2018, 10, 1093. [CrossRef]

231. Jiang, N.M.; Cowan, M.; Moonah, S.N.; Petri, W.A. The Impact of Systemic Inflammation on Neurodevelopment. Trends Mol. Med. 2018, 24, 794-804. [CrossRef]

232. Deverman, B.E.; Patterson, P.H. Cytokines and CNS development. Neuron 2009, 64, 61-78. [CrossRef]

233. Kuban, K.C.; O'Shea, T.M.; Allred, E.N.; Fichorova, R.N.; Heeren, T.; Paneth, N.; Hirtz, D.; Dammann, O.; Leviton, A.; ELGAN Study Investigators. The breadth and type of systemic inflammation and the risk of adverse neurological outcomes in extremely low gestation newborns. Pediatr. Neurol. 2015, 52, 42-48. [CrossRef]

234. Goeden, N.; Velasquez, J.; Arnold, K.A.; Chan, Y.; Lund, B.T.; Anderson, G.M.; Bonnin, A. Maternal Inflammation Disrupts Fetal Neurodevelopment via Increased Placental Output of Serotonin to the Fetal Brain. J. Neurosci. 2016, 36, 6041-6049. [CrossRef]

235. O'Shea, T.M.; Joseph, R.M.; Kuban, K.C.; Allred, E.N.; Ware, J.; Coster, T.; Fichorova, R.N.; Dammann, O.; Leviton, A.; ELGAN Study Investigators. Elevated blood levels of inflammation-related proteins are associated with an attention problem at age $24 \mathrm{mo}$ in extremely preterm infants. Pediatr. Res. 2014, 75, 781-787.

236. Jiang, N.M.; Tofail, F.; Moonah, S.N.; Scharf, R.J.; Taniuchi, M.; Ma, J.Z.; Hamadani, J.D.; Gurley, E.S.; Houpt, E.R.; Azziz-Baumgartner, E.; et al. Febrile illness and pro-inflammatory cytokines are associated with lower neurodevelopmental scores in Bangladeshi infants living in poverty. BMC Pediatr. 2014, 14, 50. [CrossRef]

237. Scheller, J.; Chalaris, A.; Schmidt-Arras, D.; Rose-John, S. The pro- and anti-inflammatory properties of the cytokine interleukin. Biochim. Biophys. Acta BBA Bioenerg. 2011, 1813, 878-888. [CrossRef]

238. Hayden, K.M.; Beavers, D.P.; Steck, S.E.; Hebert, J.R.; Tabung, F.K.; Shivappa, N.; Casanova, R.; Manson, J.E.; Padula, C.B.; Salmoirago-Blotcher, E.; et al. The association between an inflammatory diet and global cognitive function and incident dementia in older women: The Women's Health Initiative Memory Study. Alzheimers Dement. 2017, 13, 1187-1196. [CrossRef] 
239. Kesse-Guyot, E.; Assmann, K.E.; Andreeva, V.A.; Touvier, M.; Neufcourt, L.; Shivappa, N.; Hébert, J.R.; Wirth, M.D.; Hercberg, S.; Galan, P.; et al. Long-term association between the dietary inflammatory index and cognitive functioning: Findings from the SU.VI.MAX study. Eur. J. Nutr. 2017, 56, 1647-1655. [CrossRef]

240. Assmann, K.E.; Hébert, J.R.; Wirth, M.D.; Hercberg, S.; Adjibade, M.; Shivappa, N.; Touvier, M.; Akbaraly, T.; Galan, P.; Julia, C.; et al. The Inflammatory Potential of the Diet at Midlife Is Associated with Later Healthy Aging in French Adults. J. Nutr. 2018, 148, 437-444. [CrossRef]

241. Frith, E.; Shivappa, N.; Mann, J.R.; Hebert, J.R.; Wirth, M.D.; Loprinzi, P.D. Dietary inflammatory index and memory function: Population-based national sample of elderly Americans. Br. J. Nutr. 2018, 119, 552-558. [CrossRef]

242. Frith, E.; Shivappa, N.; Mann, J.R.; Hebert, J.R.; Wirth, M.D.; Loprinzi, P.D. Letter to Editor in response to: Potential confounding in a study of dietary inflammatory index and cognitive function. Br. J. Nutr. 2018, 120, 1078-1079. [CrossRef]

243. Shin, D.; Kwon, S.C.; Kim, M.H.; Lee, K.W.; Choi, S.Y.; Shivappa, N.; Hébert, J.R.; Chung, H.K. Inflammatory potential of diet is associated with cognitive function in an older adult Korean population. Nutrition 2018, 55-56, 56-62. [CrossRef]

244. Whiteford, H.; Ferrari, A.; Degenhardt, L. Global Burden Of Disease Studies: Implications For Mental And Substance Use Disorders. Health Aff. 2016, 35, 1114-1120. [CrossRef]

245. World Health Organisation. Depression and Other Common Mental Disorders: Global Health Estimates; World Health Organization: Geneva, Switherland, 2017.

246. WHO. Risks to Mental Health: An Overview of Vulnerabilities and Risk Factors; Background Paper by WHO Secretariat for the Development of a Comprehensive Mental Health Action Plan; World Health Organization: Geneva, Switherland, 2012.

247. Akbaraly, T.N.; Brunner, E.J.; Ferrie, J.E.; Marmot, M.G.; Kivimäki, M.; Singh-Manoux, A. Dietary pattern and depressive symptoms in middle age. Br. J. Psychiatry 2009, 195, 408-413. [CrossRef]

248. Sanchez-Villegas, A.; Toledo, E.; de Irala, J.; Ruiz-Canela, M.; Pla-Vidal, J.; Martinez-Gonzalez, M.A. Fast-food and commercial baked goods consumption and the risk of depression. Public Health Nutr. 2012, 15, 424-432. [CrossRef]

249. Lai, J.S.; Hiles, S.; Bisquera, A.; Hure, A.J.; McEvoy, M.; Attia, J. A systematic review and meta-analysis of dietary patterns and depression in community-dwelling adults. Am. J. Clin. Nutr. 2014, 99, 181-197. [CrossRef]

250. Quirk, S.E.; Williams, L.J.; O’Neil, A.; Pasco, J.A.; Jacka, F.N.; Housden, S.; Berk, M.; Brennan, S.L. The association between diet quality, dietary patterns and depression in adults: A systematic review. BMC Psychiatry 2013, 13, 175. [CrossRef]

251. Kivimaki, M.; Shipley, M.J.; Batty, G.D.; Hamer, M.; Akbaraly, T.N.; Kumari, M.; Jokela, M.; Virtanen, M.; Lowe, G.D.; Ebmeier, K.P.; et al. Long-term inflammation increases risk of common mental disorder: A cohort study. Mol. Psychiatry 2014, 19, 149-150. [CrossRef]

252. Köhler, C.A.; Freitas, T.H.; Maes, M.; De Andrade, N.Q.; Liu, C.S.; Fernandes, B.S.; Stubbs, B.; Solmi, M.; Veronese, N.; Herrmann, N.; et al. Peripheral cytokine and chemokine alterations in depression: A meta-analysis of 82 studies. Acta Psychiatr. Scand. 2017, 135, 373-387. [CrossRef]

253. Lassale, C.; Batty, G.D.; Baghdadli, A.; Jacka, F.; Sánchez-Villegas, A.; Kivimäki, M.; Akbaraly, T. Correction: Healthy dietary indices and risk of depressive outcomes: A systematic review and meta-analysis of observational studies. Mol. Psychiatry 2018, 24, 1094. [CrossRef]

254. Molendijk, M.; Molero, P.; Sánchez-Pedreño, F.O.; Van Der Does, W.; Martínez-González, M.A. Diet quality and depression risk: A systematic review and dose-response meta-analysis of prospective studies. J. Affect. Disord. 2018, 226, 346-354. [CrossRef]

255. Tolkien, K.; Bradburn, S.; Murgatroyd, C. An anti-inflammatory diet as a potential intervention for depressive disorders: A systematic review and meta-analysis. Clin. Nutr. 2018, 20, 20. [CrossRef]

256. Kheirouri, S.; Alizadeh, M. Dietary Inflammatory Potential and the Risk of Incident Depression in Adults: A Systematic Review. Adv. Nutr. 2019, 10, 9-18. [CrossRef]

257. Wang, J.; Zhou, Y.; Chen, K.; Jing, Y.; He, J.; Sun, H.; Hu, X. Dietary inflammatory index and depression: A meta-analysis. Public Health Nutr. 2018, 1-7. [CrossRef]

258. Firth, J.; Stubbs, B.; Teasdale, S.B.; Ward, P.B.; Veronese, N.; Shivappa, N.; Hebert, J.R.; Berk, M.; Yung, A.R.; Sarris, J. Diet as a hot topic in psychiatry: A population-scale study of nutritional intake and inflammatory potential in severe mental illness. World Psychiatry 2018, 17, 365-367. [CrossRef] 
259. Shivappa, N.; Hebert, J.R.; Tehrani, A.N.; Bayzai, B.; Naja, F.; Rashidkhani, B. A Pro-Inflammatory Diet Is Associated With an Increased Odds of Depression Symptoms Among Iranian Female Adolescents: A Cross-Sectional Study. Front. Psychol. 2018, 9, 400. [CrossRef]

260. Shivappa, N.; Schoenaker, D.A.J.M.; Hebert, J.R.; Mishra, G.D. Association between inflammatory potential of diet and risk of depression in middle-aged women: The Australian Longitudinal Study on Women's Health. Br. J. Nutr. 2016, 116, 1077-1086. [CrossRef]

261. Adjibade, M.; Andreeva, V.A.; Lemogne, C.; Touvier, M.; Shivappa, N.; Hébert, J.R.; Wirth, M.D.; Hercberg, S.; Galan, P.; Julia, C.; et al. The Inflammatory Potential of the Diet Is Associated with Depressive Symptoms in Different Subgroups of the General Population. J. Nutr. 2017, 147, 879-887. [CrossRef]

262. Phillips, C.M.; Shivappa, N.; Hébert, J.R.; Perry, I.J. Dietary inflammatory index and mental health: A cross-sectional analysis of the relationship with depressive symptoms, anxiety and well-being in adults. Clin. Nutr. 2018, 37, 1485-1491. [CrossRef]

263. Akbaraly, T.N.; Kerlau, C.; Wyart, M.; Chevallier, N.; Ndiaye, L.; Shivappa, N.; Hébert, J.R.; Kivimäki, M. Dietary inflammatory index and recurrence of depressive symptoms: Results from the Whitehall II Study. Clin. Psychol. Sci. 2016, 4, 1125-1134. [CrossRef]

264. Sánchez-Villegas, A.; Ruíz-Canela, M.; De La Fuente-Arrillaga, C.; Gea, A.; Shivappa, N.; Hébert, J.R.; Martínez-González, M.A. Dietary inflammatory index, cardiometabolic conditions and depression in the Seguimiento Universidad de Navarra cohort study. Br. J. Nutr. 2015, 114, 1471-1479. [CrossRef]

265. Shivappa, N.; Hebert, J.R.; Veronese, N.; Caruso, M.G.; Notarnicola, M.; Maggi, S.; Stubbs, B.; Firth, J.; Fornaro, M.; Solmi, M. The relationship between the dietary inflammatory index (DII((R))) and incident depressive symptoms: A longitudinal cohort study. J. Affect. Disord. 2018, 235, 39-44. [CrossRef]

266. Hauenstein, E.J. Young women and depression. Origin, outcome, and nursing care. Nurs. Clin. N. Am. 1991, 26, 601-612.

267. WHO. WHO Fact Sheets; Depression; World Health Organization: Geneva, Switzerland, 2018.

268. Knott, L.; Avery, N.; Hollander, A.; Tarlton, J. Regulation of osteoarthritis by omega-3 (n-3) polyunsaturated fatty acids in a naturally occurring model of disease. Osteoarthr. Cartil. 2011, 19, 1150-1157. [CrossRef]

269. Mabey, T.; Honsawek, S. Role of Vitamin D in Osteoarthritis: Molecular, Cellular, and Clinical Perspectives. Int. J. Endocrinol. 2015, 2015, 1-14. [CrossRef]

270. Shen, C.-L.; Smith, B.J.; Lo, D.-F.; Chyu, M.-C.; Dunn, D.M.; Chen, C.-H.; Kwun, I.-S. Dietary polyphenols and mechanisms of osteoarthritis. J. Nutr. Biochem. 2012, 23, 1367-1377. [CrossRef]

271. Veronese, N.; Stubbs, B.; Noale, M.; Solmi, M.; Luchini, C.; Smith, T.O.; Cooper, C.; Guglielmi, G.; Reginster, J.Y.; Rizzoli, R.; et al. Adherence to a Mediterranean diet is associated with lower prevalence of osteoarthritis: Data from the osteoarthritis initiative. Clin. Nutr. 2017, 36, 1609-1614. [CrossRef]

272. Barbour, K.E.; Boudreau, R.; Danielson, M.E.; Youk, A.O.; Wactawski-Wende, J.; Greep, N.C.; Lacroix, A.Z.; Jackson, R.D.; Wallace, R.B.; Bauer, D.C.; et al. Inflammatory Markers and the Risk of Hip Fracture: The Women's Health Initiative. J. Bone Miner. Res. 2012, 27, 1167-1176. [CrossRef]

273. Cauley, J.A.; Danielson, M.E.; Boudreau, R.M.; Forrest, K.Y.Z.; Zmuda, J.M.; Pahor, M.; Tylavsky, F.A.; Cummings, S.R.; Harris, T.B.; Newman, A.B. Inflammatory Markers and Incident Fracture Risk in Older Men and Women: The Health Aging and Body Composition Study. J. Bone Miner. Res. 2007, 22, 1088-1095. [CrossRef]

274. Sokolove, J.; Lepus, C.M. Role of inflammation in the pathogenesis of osteoarthritis: Latest findings and interpretations. Ther. Adv. Musculoskelet. Dis. 2013, 5, 77-94. [CrossRef]

275. Orchard, T.; Yildiz, V.; Steck, S.E.; Hébert, J.R.; Ma, Y.; Cauley, J.A.; Li, W.; Mossavar-Rahmani, Y.; Johnson, K.C.; Sattari, M.; et al. Dietary Inflammatory Index, Bone Mineral Density, and Risk of Fracture in Postmenopausal Women: Results From the Women's Health Initiative. J. Bone Miner. Res. 2017, 32, 1136-1146. [CrossRef]

276. Na, W.; Park, S.; Shivappa, N.; Hebert, J.R.; Kim, M.K.; Sohn, C. Association between Inflammatory Potential of Diet and Bone-Mineral Density in Korean Postmenopausal Women: Data from Fourth and Fifth Korea National Health and Nutrition Examination Surveys. Nutrients 2019, 11, 885. [CrossRef]

277. Shivappa, N.; Hebert, J.R.; Karamati, M.; Shariati-Bafghi, S.E.; Rashidkhani, B. Increased inflammatory potential of diet is associated with bone mineral density among postmenopausal women in Iran. Eur. J. Nutr. 2016, 55, 561-568. [CrossRef]

278. Mazidi, M.; Shivappa, N.; Wirth, M.D.; Hebert, J.R.; Vatanparast, H.; Kengne, A.P. The association between dietary inflammatory properties and bone mineral density and risk of fracture in US adults. Eur. J. Clin. Nutr. 2017, 71, 1273-1277. [CrossRef] 
279. Veronese, N.; Shivappa, N.; Stubbs, B.; Smith, T.; Hébert, J.R.; Cooper, C.; Guglielmi, G.; Reginster, J.-Y.; Rizzoli, R.; Maggi, S. The relationship between the dietary inflammatory index and prevalence of radiographic symptomatic osteoarthritis: Data from the Osteoarthritis Initiative. Eur. J. Nutr. 2017, 58, 253-260. [CrossRef]

280. Veronese, N.; Stubbs, B.; Koyanagi, A.; Hebert, J.R.; Cooper, C.; Caruso, M.G.; Guglielmi, G.; Reginster, J.Y.; Rizzoli, R.; Maggi, S.; et al. Pro-inflammatory dietary pattern is associated with fractures in women: An eight-year longitudinal cohort study. Osteoporos. Int. 2018, 29, 143-151. [CrossRef]

281. Zhang, Z.-Q.; Cao, W.-T.; Shivappa, N.; Hebert, J.R.; Li, B.-L.; He, J.; Tang, X.-Y.; Liang, Y.-Y.; Chen, Y.-M. Association between Diet Inflammatory Index and Osteoporotic Hip Fracture in Elderly Chinese Population. J. Am. Med. Dir. Assoc. 2017, 18, 671-677. [CrossRef]

282. Cervo, M.M.; Shivappa, N.; Hebert, J.R.; Oddy, W.H.; Winzenberg, T.; Balogun, S.; Wu, F.; Ebeling, P.; Aitken, D.; Jones, G.; et al. Longitudinal associations between dietary inflammatory index and musculoskeletal health in community-dwelling older adults. Clin. Nutr. 2019. [CrossRef]

283. Morimoto, M.; Shivappa, N.; Genaro, P.D.S.; Martini, L.A.; Schuch, N.J.; Hebert, J.R.; Pinheiro, M.M. Lack of association between dietary inflammatory index and low impact fractures in the Brazilian population: The Brazilian Osteoporosis Study (BRAZOS). Adv. Rheumatol. 2019, 59, 16. [CrossRef]

284. Amakye, W.K.; Zhang, Z.; Wei, Y.; Shivappa, N.; Hebert, J.R.; Wang, J.; Su, Y.; Mao, L. The relationship between dietary inflammatory index (DII) and muscle mass and strength in Chinese children aged 6-9 years. Asia Pac. J. Clin. Nutr. 2018, 27, 1315-1324.

285. Evans, C.H.; Mears, D.C.; McKnight, J.L. A preliminary ferrographic survey of the wear particles in human synovial fluid. Arthritis Rheum. 1981, 24, 912-918. [CrossRef]

286. Ginaldi, L.; Di Benedetto, M.C.; De Martinis, M. Osteoporosis, inflammation and ageing. Immun. Ageing 2005, 2, 14. [CrossRef]

287. Homandberg, G.A.; Hui, F. Association of Proteoglycan Degradation with Catabolic Cytokine and Stromelysin Release from Cartilage Cultured with Fibronectin Fragments. Arch. Biochem. Biophys. 1996, 334, 325-331. [CrossRef]

288. Takayanagi, H. Osteoimmunology: Shared mechanisms and crosstalk between the immune and bone systems. Nat. Rev. Immunol. 2007, 7, 292-304. [CrossRef]

289. Martin, R.; Harvey, N.C.; Crozier, S.R.; Poole, J.R.; Javaid, M.K.; Dennison, E.M.; Inskip, H.M.; Hanson, M.; Godfrey, K.M.; Cooper, C.; et al. Placental calcium transporter (PMCA3) gene expression predicts intrauterine bone mineral accrual. Bone 2007, 40, 1203-1208. [CrossRef]

290. Curtis, E.M.; Krstic, N.; Cook, E.; D’Angelo, S.; Crozier, S.R.; Moon, R.J.; Murray, R.; Garratt, E.; Costello, P.; Cleal, J.; et al. Gestational Vitamin D Supplementation Leads to Reduced Perinatal RXRA DNA Methylation: Results From the MAVIDOS Trial. J. Bone Miner. Res. 2019, 34, 231-240. [CrossRef]

291. Cooper, C.; Harvey, N.C.; Bishop, N.J.; Kennedy, S.; Papageorghiou, A.T.; Schoenmakers, I.; Fraser, R.; Gandhi, S.V.; Carr, A.; D'Angelo, S.; et al. Maternal gestational vitamin D supplementation and offspring bone health (MAVIDOS): A multicentre, double-blind, randomised placebo-controlled trial. Lancet Diabetes Endocrinol. 2016, 4, 393-402. [CrossRef]

292. Robinson, D.P.; Klein, S.L. Pregnancy and pregnancy-associated hormones alter immune responses and disease pathogenesis. Horm. Behav. 2012, 62, 263-271. [CrossRef]

293. Ingvorsen, C.; Brix, S.; Ozanne, S.E.; Hellgren, L.I. The effect of maternal Inflammation on foetal programming of metabolic disease. Acta Physiol. 2015, 214, 440-449. [CrossRef]

294. Girard, S.; Tremblay, L.; Lepage, M.; Sébire, G. IL-1 Receptor Antagonist Protects against Placental and Neurodevelopmental Defects Induced by Maternal Inflammation. J. Immunol. 2010, 184, 3997-4005. [CrossRef]

295. Sureshchandra, S.; Marshall, N.E.; Wilson, R.M.; Barr, T.; Rais, M.; Purnell, J.Q.; Thornburg, K.L.; Messaoudi, I. Inflammatory Determinants of Pregravid Obesity in Placenta and Peripheral Blood. Front. Physiol. 2018, 9 , 1089. [CrossRef]

296. Segovia, S.A.; Vickers, M.H.; Gray, C.; Reynolds, C.M. Maternal Obesity, Inflammation, and Developmental Programming. BioMed Res. Int. 2014, 2014, 1-14. [CrossRef]

297. Jaenisch, R.; Bird, A. Epigenetic regulation of gene expression: How the genome integrates intrinsic and environmental signals. Nat. Genet. 2003, 33, 245-254. [CrossRef]

298. Barker, D.; Osmond, C. Infant mortality, childhood nutrition, and ischaemic heart disease in england and wales. Lancet 1986, 327, 1077-1081. [CrossRef] 
299. Vansant, G.W.S.; Godderis, L. Effect of maternal and paternal nutrition on DNA methylation in the offspring: A systematic review of human and animal studies. Adv. Obes. Weight Manag. Control 2016, 4, 81-97. [CrossRef]

300. Rakyan, V.K.; Blewitt, M.E.; Druker, R.; Preis, J.I.; Whitelaw, E. Metastable epialleles in mammals. Trends Genet. 2002, 18, 348-351. [CrossRef]

301. James, P.T.; Dominguez-Salas, P.; Hennig, B.J.; Moore, S.E.; Prentice, A.M.; Silver, M.J. Maternal One-Carbon Metabolism and Infant DNA Methylation between Contrasting Seasonal Environments: A Case Study from The Gambia. Curr. Dev. Nutr. 2019, 3, nzy082. [CrossRef]

302. Sen, S.; Rifas-Shiman, S.L.; Shivappa, N.; Wirth, M.D.; Hebert, J.R.; Gold, D.R.; Gillman, M.W.; Oken, E. Associations of prenatal and early life dietary inflammatory potential with childhood adiposity and cardiometabolic risk in Project Viva. Pediatr. Obes. 2018, 13, 292-300. [CrossRef]

303. Moore, B.F.; Sauder, K.A.; Starling, A.P.; Hebert, J.R.; Shivappa, N.; Ringham, B.M.; Glueck, D.H.; Dabelea, D. Proinflammatory Diets during Pregnancy and Neonatal Adiposity in the Healthy Start Study. J. Pediatr. 2018, 195, 121-127. [CrossRef]

304. McCullough, L.E.; Miller, E.E.; Calderwood, L.E.; Shivappa, N.; Steck, S.E.; Forman, M.R.; Mendez, M.A.; Maguire, R.; Fuemmeler, B.F.; Kollins, S.H.; et al. Maternal inflammatory diet and adverse pregnancy outcomes: Circulating cytokines and genomic imprinting as potential regulators? Epigenetics 2017, 12, 688-697. [CrossRef]

305. Hill, A.B. Observation and Experiment. N. Engl. J. Med. 1953, 248, 3-9. [CrossRef]

306. Hill, A.B. The Environment and Disease: Association or Causation? Proc. R. Soc. Med. 1965, 58, $295-300$. [CrossRef]

307. Hebert, J.R.; Frongillo, E.A.; Adams, S.A.; Turner-McGrievy, G.M.; Hurley, T.G.; Miller, D.R.; Ockene, I.S. Perspective: Randomized Controlled Trials Are Not a Panacea for Diet-Related Research. Adv. Nutr. 2016, 7, 423-432. [CrossRef]

308. Hebert, J.R.; Hurley, T.G.; Steck, S.E.; Miller, D.R.; Tabung, F.K.; Peterson, K.E.; Kushi, L.H.; Frongillo, E.A. Considering the value of dietary assessment data in informing nutrition-related health policy. Adv. Nutr. 2014, 5, 447-455. [CrossRef]

309. Fraser, A.; Macdonald-Wallis, C.; Tilling, K.; Boyd, A.; Golding, J.; Davey Smith, G.; Henderson, J.; Macleod, J.; Molloy, L.; Ness, A.; et al. Cohort Profile: The Avon Longitudinal Study of Parents and Children: ALSPAC mothers cohort. Int. J. Epidemiol. 2013, 42, 97-110. [CrossRef]

310. Heude, B.; Forhan, A.; Slama, R.; Douhaud, L.; Bedel, S.; Saurel-Cubizolles, M.J.; Hankard, R.; Thiebaugeorges, O.; De Agostini, M.; Annesi-Maesano, I.; et al. Cohort Profile: The EDEN mother-child cohort on the prenatal and early postnatal determinants of child health and development. Int. J. Epidemiol. 2016, 45, 353-363. [CrossRef]

311. Inskip, H.M.; Godfrey, K.M.; Robinson, S.M.; Law, C.M.; Barker, D.J.; Cooper, C.; SWS Study Group. Cohort profile: The Southampton Women's Survey. Int. J. Epidemiol. 2006, 35, 42-48. [CrossRef]

312. Kelleher, C.C.; Viljoen, K.; Khalil, H.; Somerville, R.; O’Brien, J.; Shrivastava, A.; Murrin, C.; Lifeways Cross-Generation Cohort Study Steering Group. Longitudinal follow-up of the relationship between dietary intake and growth and development in the Lifeways cross-generation cohort study 2001-2003. Proc. Nutr. Soc. 2014, 73, 118-131. [CrossRef]

313. Kooijman, M.N.; Kruithof, C.J.; van Duijn, C.M.; Duijts, L.; Franco, O.H.; van IJzendoorn, M.H.; de Jongste, J.C.; Klaver, C.C.W.; van der Lugt, A.; Mackenbach, J.P.; et al. The Generation R Study: Design and cohort update 2017. Eur. J. Epidemiol. 2016, 31, 1243-1264. [CrossRef]

314. Polańska, K.; Hanke, W.; Król, A.; Potocka, A.; Waszkowska, M.; Jacukowicz, A.; Jerzyńska, J.; Stelmach, W.; Stelmach, I.; Gromadzińska, J.; et al. Polish mother and child cohort study (REPRO_PL)—Methodology of the follow-up of the children at the age of 7. Int. J. Occup. Med. Environ. Health 2016, 29, 883-893. [CrossRef]

315. Walsh, J.M.; McGowan, C.A.; Mahony, R.; Foley, M.E.; McAuliffe, F.M. Low glycaemic index diet in pregnancy to prevent macrosomia (ROLO study): Randomised control trial. BMJ 2012, 345, e5605. [CrossRef]

(C) 2019 by the authors. Licensee MDPI, Basel, Switzerland. This article is an open access article distributed under the terms and conditions of the Creative Commons Attribution (CC BY) license (http://creativecommons.org/licenses/by/4.0/). 